\title{
The vitamin E nutritional status of rats fed on diets high in fish oil, linseed oil or sunflower seed oil
}

\author{
BY SANDRA R. FARWER \\ Rheinische Friedrich-Wilhelms-Universität Bonn, Germany \\ AND BERNARDUS C. J. DER BOER*, EDWARD HADDEMAN, \\ GERARDUS A. A. KIVITS, ANTOON WIERSMA \\ AND BERRY H. J. C. DANSE ${ }^{2}$ \\ Unilever Research Laboratorium Vlaardingen, Olivier van Noortlaan 120,3133 AT Vlaardingen, \\ The Netherlands
}

(Received 18 November 1992 - Revised 4 August 1993-Accepted 28 October 1993)

\begin{abstract}
Twelve groups of eight rats and two control groups of sixteen rats were given semisynthetic diets with $40 \%$ energy as fat for a period of $76 \mathrm{~d}$. All diets contained a minimum of $3 \%$ energy as linoleic acid and comparable basal levels of $D-\alpha$ - and $D-\gamma$-tocopherol. The diets varied in fat composition and in the content of DL- $\alpha$-tocopheryl acetate. The diets high in polyunsaturated fatty acids (PUFA) were either rich in fish oil (FO; groups 1-4; $10 \%$ energy as fish oil PUFA), linseed oil (LN; groups $1-4 ; 10 \%$ energy as $\alpha$-linolenic acid) or sunflower seed oil (SF; groups $1-4 ; 10+3 \%$ energy as linoleic acid). The control groups were given a diet high in monounsaturated fatty acids (MUFA; CO 1; 10+13\% energy as oleic acid) or a diet with an 'average' linoleic acid content (CO 2; 8.5\% energy as linoleic acid). Of each high PUFA diet three groups were supplemented with graded levels of DL- $\alpha$-tocopheryl acetate. Steatitis, a sensitive histopathological indicator of vitamin $\mathbf{E}$ deficiency in animals fed on diets rich in fatty acids with three or more double bonds, was observed only in the adipose tissue of the FO groups, even in the group with the highest DL- $\alpha$-tocopheryl acetate supplementation. Liver and serum $\alpha$ tocopherol levels were found to be positively correlated and liver and serum $\gamma$-tocopherol levels negatively correlated with dietary DL- $\alpha$-tocopheryl acetate. The groups on the FO diets had significantly reduced liver and serum tocopherol levels in comparison with the groups on the other high-PUFA diets. With the supplementation scheme used for the FO groups the liver $\alpha$-tocopherol levels of both control groups were reached but the serum control levels were not.
\end{abstract}

Vitamin E: Polyunsaturated fatty acids: Steatitis

Not until 1968 was vitamin $E$ recognized formally as an essential nutrient for humans and included in the Recommended Dietary Allowance (RDA) table of the Food and Nutrition Board of the US National Research Council (Food and Nutrition Board, 1968). The first recommended daily intake of vitamin $E, 30$ international units (1 IU $=1 \mathrm{mg}$ DL- $\alpha-$ tocopheryl acetate) for adults, was calculated using the following formula: IU required = $(1.25)$ (kg body wt) ${ }^{0.75}$ (based on Harris, 1949). In the eighth edition of the RDA table (Food and Nutrition Board, 1974), after realizing that the average requirement as well as the average intake of vitamin $E$ was much lower than $30 \mathrm{IU}$, the recommended intake for male adults was reduced to $15 \mathrm{IU}$. This was also advised in the tenth edition of the RDA table (Food and Nutrition Board, 1989) only expressed as tocopherol equivalents (10 TE $=10 \mathrm{mg} \mathrm{D}$ - $\alpha$-tocopherol $=15 \mathrm{IU})$. Most countries not only give a fixed value for the

\footnotetext{
* For reprints.
} 
vitamin $E$ requirement but also point out that the vitamin $E$ requirement increases with an increasing PUFA intake. In Germany (Deutsche Gesellschaft für Ernährung, 1986), a 'desirable intake' of $12 \mathrm{mg}$ TE for male adults (with an average PUFA consumption) was estimated by adding up a basic need of $6.0 \mathrm{mg}$ TE, an extra need of $0.5 \mathrm{mg}$ TE/g PUFA for intakes exceeding $7 \mathrm{~g}$ PUFA/d, and a 'factor of safety' of $10 \%$. In the Report on Dietary Reference Values for Food, Energy and Nutrients for the UK (Department of Health, 1991) no fixed value for the vitamin $E$ requirement/d or per amount of PUFA in the diet was given. However, a qualitative statement that supplements of PUFA (usually not linoleic acid) should contain adequate amounts of vitamin $E$ was given.

Horwitt (1960) stated that the vitamin E requirement depends on the amount of peroxidizable lipid in tissues and therefore, indirectly, on the amount present in the diet. In 1964 Witting \& Horwitt concluded from animal experiments that it is the degree of unsaturation of the (poly) unsaturated fatty acids as well as the total unsaturation (total number of double bonds) of the dietary lipids which determine the vitamin $E$ requirement. They estimated that the relative molar quantities of tocopherol required to protect monoenoic, dienoic, trienoic, tetraenoic, pentaenoic, and hexaenoic acids can be described by the ratios $0 \cdot 3: 2: 3: 4: 5: 6$. Harris \& Embree (1963) compared the vitamin E:PUFA ratio as calculated to be present in a daily available average US consumer's diet with the results of the 'Elgin Study' (Horwitt, 1960) and stated; 'For discussion and evaluation of diets $0.6(\mathrm{mg} / \mathrm{g})$ shall be used as the critical ratio, since it is the ratio for the total average US diet and it is generally adequate'. Ten years later a ratio of 0.4 has been regarded as satisfactory in average American diets (Bieri \& Evarts, 1973; Witting \& Lee, 1975). Jager (1975), in a series of experiments with various animal models, investigated the vitamin E:PUFA (linoleic acid) ratio. He did not find a linear increase in the vitamin $E$ requirement with increasing levels of linoleic acid in the diet and therefore criticized the concept of the critical dietary vitamin E:PUFA ratio in the diet. He also pointed out that vegetable oils (if properly processed) are the best dietary source of linoleic acid as well as vitamin $\mathrm{E}$.

Recent discussions about an 'optimum biological antioxidant status' make it interesting to reinvestigate the vitamin E-PUFA relationship. Not only should D- $\alpha-$ tocopherol and linoleic acid, the dominant types of vitamin $E$ and PUFA in the diet, be studied further, but also research into the influence of $n-3$ fatty acids and $\gamma$-tocopherol on the vitamin E status, where present knowledge is rather limited, should be carried out. In order to be able to determine the optimal vitamin $E$ status it is important to know to what extent the various PUFA influence the vitamin $E$ concentrations in tissues and to have sensitive measures available, independent of the type of dietary PUFA (other than the commonly used deficiency criteria), that can prove that a certain vitamin $E$ status gives adequate antioxidant protection.

In this study we investigated the effects of three different high-PUFA diets on the vitamin $E$ nutritional status of rats. In order to learn about the adequacy of the vitamin $E$ status the animals on the high-PUFA diets were checked for steatitis, which is an early symptom of vitamin $\mathrm{E}$ deficiency that occurs when diets are rich in fatty acids with three or more double bonds (Danse, 1989).

\section{METHODS}

\section{Animals}

Male VAF (Virus Antibody Free) Wistar rats ( $n$ 128; Charles River, Wiga GmbH, Sulzfeld, Germany) weighing approximately $50 \mathrm{~g}(21 / 22 \mathrm{~d}$ old $)$ received the dietary treatment for a period of $76 \mathrm{~d}$. The rats were housed individually; average temperature and humidity were $23 \pm 1^{\circ}$ and $55 \pm 10 \%$ respectively, and a day-night cycle of $12 \mathrm{~h}$ was observed. Fresh food (supplied daily) and water were provided $a d$ lib. Sixteen groups of eight rats each were 
allocated at random, based on body weight. The body weight of each animal was recorded weekly. Individual food consumption was recorded for two $24 \mathrm{~h}$ periods on three occasions, on days $21-22,46-47$ and $70-71$ of the experimental feeding period. All experimental groups showed comparable food intake and body weight gain. During the experimental period, tail blood of non-fasting animals was taken on days 24,52 and 76 .

\section{Dietary treatment}

Basic diet. All groups of animals received semisynthetic diets providing $40 \%$ energy as fat $(187.8 \mathrm{~g}$ fat $/ \mathrm{kg}$ ), containing $(\mathrm{g} / \mathrm{kg})$ : calcium caseinate $265 \cdot 0$, maize starch $461 \cdot 6$, cellulose 65.5, mineral mixture 15.7, vitamin mixture (without vitamin E) 4.4 and experimental fat mixture 187.8. The mineral mixture comprised $(\mathrm{mg} / \mathrm{kg}): \mathrm{KCl} 1526.4, \mathrm{MgHPO}_{4} .3 \mathrm{H}_{2} \mathrm{O}$ 4169.2, $\mathrm{KH}_{2} \mathrm{PO}_{4}, 2071 \cdot 5, \mathrm{KHCO}_{3} 3135 \cdot 6, \mathrm{CaCO}_{3} 1286 \cdot 5, \mathrm{C}_{6} \mathrm{H}_{5} \mathrm{Na}_{3} \mathrm{O}_{7} .2 \mathrm{H}_{2} \mathrm{O} 3100 \cdot 8$, $\mathrm{MnSO}_{4} \cdot \mathrm{H}_{2} \mathrm{O} 224 \cdot 4, \mathrm{C}_{6} \mathrm{H}_{5} \mathrm{FeO}_{7} .5 \mathrm{H}_{2} \mathrm{O} 191 \cdot 4, \mathrm{Cu}_{2} \mathrm{C}_{6} \mathrm{H}_{6} \mathrm{O}_{8} . \mathrm{H}_{2} \mathrm{O} 20 \cdot 5, \mathrm{Zn}_{2} \mathrm{C}_{6} \mathrm{H}_{6} \mathrm{O}_{8} 54 \cdot 5, \mathrm{KIO}_{3}$ 0.3 . The vitamin mixture comprised $(\mathrm{mg} / \mathrm{kg})$ : choline chloride $(50 \%) 2200$, myo-inositol 110 , calcium silicate 220 , calcium pantothenic acid 22 , niacin 22 , biotin $1 \cdot 1$, vitamin A $(98 \cdot 5$ retinol equivalents $/ \mathrm{mg}$ ) $33 \cdot 88$, thiamin $6 \cdot 6$, riboflavin $6 \cdot 6$, pyridoxine $2 \cdot 2$, cyanocobalamin $(1000 \mathrm{mg} / \mathrm{kg}) 22 \cdot 0$, cholecalciferol $(2 \mu \mathrm{g} / \mathrm{mg}) 13 \cdot 64$, menadione $(22 \cdot 7 \%) 4 \cdot 4$, pteroylmonoglutamic acid $1 \cdot 1$, sucrose 1731 .

To avoid lipid peroxidation the following measures were taken: first, the diets were prepared eight times during the experimental period; second, the diets were stored at $-20^{\circ}$ under $\mathrm{N}_{2}$; third, fresh diets, replacing the old diets, were given daily. Furthermore, similar diets to the experimental ones were checked for their $\alpha$ - and $\gamma$-tocopherol concentration after storage for $9 \mathrm{~d}$ at $-70^{\circ}$ or at $-20^{\circ}$ under $\mathrm{N}_{2}$, and were compared with diets stored for $8 \mathrm{~d}$ at $-70^{\circ}$ or at $-20^{\circ}$ under $\mathrm{N}_{2}$ and for $24 \mathrm{~h}$ at $23^{\circ}$ in an animal room. No significant difference (FO $P>0.63$; LN $P>0.21$; SF $P>0.33$ ) in the $\alpha$ - and $\gamma$-tocopherol concentration was observed between diets stored at $-70^{\circ}$ or $-20^{\circ}$ for $9 \mathrm{~d}$.

Storage for $24 \mathrm{~h}$ at $23^{\circ}$ did not result in significant decreases of $\alpha$ - and $\gamma$-tocopherol in the FO diet $(P>0.32$ and $P>0.75$ respectively) or the LN $\operatorname{diet}(P=0.15$ and $P>0.52$ respectively). However, significant decreases of $\alpha$ - and $\gamma$-tocopherol $(P<0.01$ and $P<0.02$ ) of approximately $16 \%$ and $7 \%$ respectively were observed in the SF diet, compared with the diets stored at $-70^{\circ}$ or $-20^{\circ}$.

Experimental fat mixtures. Five experimental fat mixtures were prepared from the following natural oils: menhaden oil, sunflower-seed oil high in linoleic acid, sunflower-seed oil high in oleic acid, linseed oil, olive oil and cocoa butter. Based on the analysed fatty acid compositions of the oils, fat mixtures containing the required fatty acid compositions were prepared. All fat mixtures (supplying $40 \%$ energy of the diet) contained a minimum of $13 \%$ energy (of total diet) as saturated fatty acids (SAFA), 13\% energy as monounsaturated fatty acids (MUFA) and $3 \%$ energy as linoleic acid (to supply essential fatty acids). The remaining $10 \%$ fat energy was present in the first fat mixture as polyenoic acids (fish oil; $\boldsymbol{n}$ - 3 fatty acids; FO diet), in the second as trienoic acids (linseed oil, $\boldsymbol{n}$ - 3 fatty acids; LN diet) and in the third group as dienoic acids (sunflower-seed oil; $n-6$ fatty acids; SF diet). These fat mixtures each had a polyunsaturated:saturated fatty acid $(P: S)$ ratio of unity and were considered as the high-PUFA fats under investigation. A fourth mixture received the $10 \%$ fat energy as MUFA (control group CO $1 ; \mathrm{P}: \mathrm{S} 0.23$ ) and a fifth mixture contained an extra $4.5 \%$ energy as SAFA and $5.5 \%$ energy as dienoic acids (CO 2; $P: S 0.48)$ and these were chosen as control fat mixtures. The exact concentration of SAFA, MUFA, dienoic, trienoic and polyenoic acids in the fat mixtures, as calculated from the composition of the natural oils, is given in Table 1. Each high-PUFA fat mixture was given to four groups of eight animals, both control fat mixtures were given to two groups of sixteen animals. 
Table 1. Fatty acid composition (\% energy of the total diet) and vitamin $E$ content (tocopherol equivalents, $\left.T E^{*}\right)$ of control $(C O)$ diets and experimental diets containing fish oil $(F O)$, linseed oil $(L N)$ or sunflower-seed oil $(S F)$ fed to rats§

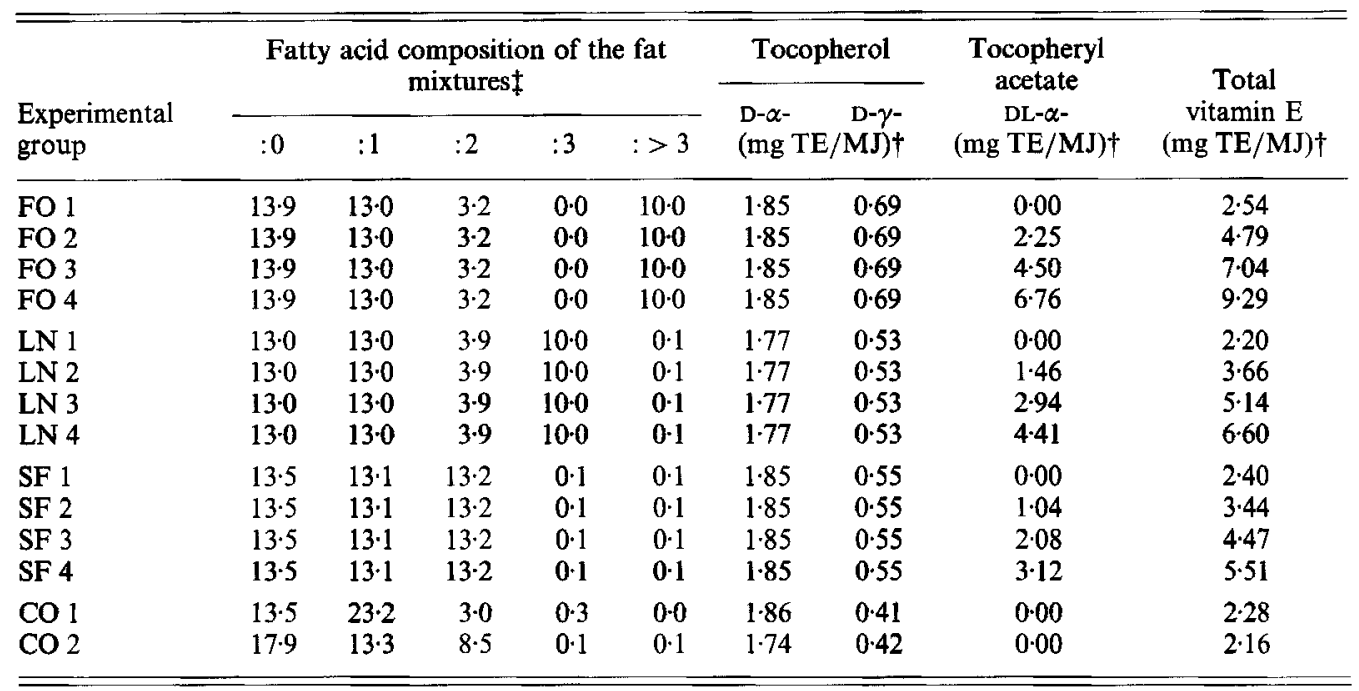

$: 0$, saturated fatty acids; $: 1$, monounsaturated fatty acids; $: 2$ dienoic fatty acids; $: 3$, trienoic fatty acids; $:>3$, polyenoic fatty acids.

* $1 \mathrm{mg} \mathrm{D}$ - $\alpha$-tocopherol = $1 \mathrm{TE} ; 1 \mathrm{mg} \mathrm{D}-\gamma$-tocopherol $=0.25 \mathrm{TE} ; 1 \mathrm{mg} \mathrm{DL}-\alpha$-tocopheryl acetate $=0.67 \mathrm{TE}$.

$\dagger$ Multiplication by 18.27 gives $\mathrm{mg} \mathrm{TE} / \mathrm{kg}$.

\$ Calculated from the analysed fatty acid composition of the natural oils used for preparation.

$\S$ For details of diets and procedures, see pp. 128-131.

Vitamin $E$ concentration in experimental fat mixtures. The analysed $\alpha$ - and $\gamma$-tocopherol concentrations of the natural oils were used to calculate the tocopherol levels of the experimental fat mixtures. By adding D- $\alpha$-tocopherol (Sigma, no. T3634) and D- $\gamma$ tocopherol (Kodak, cat. no. 118.7962 and Fluka, cat. no. 89560) it was attempted to obtain comparable amounts of $\alpha$-and $\gamma$-tocopherol in all fat mixtures. The fat mixtures were then analysed for their $\alpha$ - and $\gamma$-tocopherol concentrations (see Table 1).

Supplementation of $D L-\alpha$-tocopheryl acetate. One of each high-PUFA group (FO 1, LN 1 and SF 1) and both control groups (CO 1, CO 2) were not supplemented with vitamin $\mathrm{E}$. The amounts of DL- $\alpha$-tocopheryl acetate $(1 \mathrm{mg}=1.49 \mathrm{mg} \mathrm{TE})$ added to the remaining high-PUFA groups were determined by the number of double bonds per PUFA in the fat mixture and were calculated as follows: as a basis, $0.3 \mathrm{mg}$ TE per double bond in the PUFA was chosen (e.g. 18:2 0.6 mg TE/g, 18:3 0.9, 20:4 1.2 etc.). One group on each PUFA diet received $50 \%$ (FO 2, LN 2, SF 2), a second group received $100 \%$ (FO 3, LN 3, SF 3) and a third group received $150 \%$ (FO 4, LN 4, SF 4) of this amount (Table 1). The DL- $\alpha-$ tocopheryl acetate, a powder, was added to the dry diet before the experimental fat mixture was added.

\section{Vitamin $E$ analysis}

All solvents used were HPLC-grade and all procedures were performed in subdued nonfluorescent light.

Oils and fats. The D- $\alpha$-tocopherol contents of the natural oils and those of the experimental fat mixtures were determined by an external standard method. Samples $(200 \mathrm{mg}$ ) were weighed to the nearest $0.1 \mathrm{mg}$ and dissolved in $5.0 \mathrm{ml}$ of chloroform- 
methanol $(2: 1, v / v)$. Portions of this solution $(20 \mu \mathrm{l})$ were injected onto the HPLC column. Stock solutions of $\alpha$ - and $\gamma$-tocopherol in methanol were prepared and concentrations determined spectrophotometrically using extinction coefficients $\left(\mathrm{E} 1 \% \mathrm{~cm}^{-1}\right)$ of 71.8 and 85.6 respectively. Appropriate dilutions were analysed similarly by HPLC.

\section{Sample preparation}

Serum. This procedure is derived from that of de Leenheer et al. (1979). Briefly, $2 \mathrm{ml}$ ethanol-water $(9: 1, \mathrm{v} / \mathrm{v})$, containing $10 \mathrm{~g}$ ascorbic acid and $0 \cdot 1 \mathrm{~g}$ pyrogallol/1 (antioxidant solution), was added to $0.1 \mathrm{ml}$ serum and the mixture extracted with an internal standard (IS) solution ( $\alpha$-tocopheryl acetate) in hexane.

Liver. Immediately after killing, the liver was removed and a representative sample $(150-200 \mathrm{mg})$ of the median lobe was weighed accurately. After addition of $1.5 \mathrm{ml}$ antioxidant solution the tissue was homogenized with an ultra turrax homogenizer. The homogenate was extracted with $5.0 \mathrm{ml}$ IS solution in hexane and processed as described for serum.

\section{HPLC}

Serum and tissue extracts were evaporated to dryness under $\mathrm{N}_{2}$, the residue redissolved in chloroform-methanol $(2: 1, \mathrm{v} / \mathrm{v})$ from which $10 \mu 1$ was injected. Peaks were separated by isocratic elution with methanol-water $(100: 1 ; \mathrm{v} / \mathrm{v})$, rate $1.5 \mathrm{ml} / \mathrm{min}$ and detection at $287 \mathrm{~nm}$; peaks were identified by comparison with known reference compounds.

The HPLC equipment consisted of an Applied Biosystems (Ramsey, NJ, USA; model 400) solvent delivery pump, a Rheodyne injector (Cotati, CA, USA) provided with a $20 \mu$ l sample loop. The variable wavelength detector (Kratos 773 ; Cotati) was coupled to a Nelson ( 900 series) integration and data system for detection and quantification of peaks.

Quantification. The amounts of $\alpha$ - and $\gamma$-tocopherol in the oil samples were calculated from the relative peak areas compared with the calibration curves. Serum and tissue levels of $\alpha$ - and $\gamma$-tocopherol were calculated by comparing peak areas with that of the internal standard, with a correction for the relative absorptivities at the wavelength used:

$$
\mathrm{C}=\frac{\mathrm{S}}{\mathrm{S}_{\mathrm{IS}}} \times \mathrm{C}_{\mathrm{IS}} \times f
$$

where $\mathrm{C}$ is the concentration of $\alpha(\gamma)$-tocopherol $(\mu \mathrm{g})$ in $0.1 \mathrm{ml}$ serum or in the amount of liver sample used, $\mathrm{S}$ is the surface area of the $\alpha(\gamma)$-tocopherol peak or the IS peak, $\mathrm{C}_{\mathrm{IS}}$ is the amount of added IS $(\mu \mathrm{g})$ per sample and $f$ is a conversion factor for absorptivities and wavelength which for $\alpha$-tocopherol is 0.6074 and for $\gamma$-tocopherol is 0.6496 .

Fatty acid composition of liver triacylglycerols $(T G)$ and phospholipids $(P L)$ Extraction and class separation of lipids. Total lipids were extracted from a representative sample (approximately $200 \mathrm{mg}$ ) of the right liver lobe after homogenization with $6 \mathrm{ml}$ chloroform-methanol $(2: 1 ; \mathrm{v} / \mathrm{v})$, containing $0.1 \mathrm{~g}$ butylated hydroxytoluene $(\mathrm{BHT}) / \mathrm{l}$. After removal of solvent under $\mathrm{N}_{2}$ the lipid classes were separated on silica with appropriate hexane-ether mixtures (Hamilton \& Comai, 1988). The TG and PL fraction was transmethylated with methanolic hydrochloric acid (a 1:10 dilution of acetyl chloride in cold methanol) in the presence of BHT and the resultant fatty acid methyl esters (FAME) were analysed by GLC.

GLC analysis. FAME were analysed on a Perkin Elmer 8320 B gas-liquid chromatograph equipped with a CP Sil 88 capillary column (length $50 \mathrm{~m}$, i.d. $0.32 \mathrm{~mm}$ ) and a $\mathrm{H}_{2}$ flame ionization detector. The column temperature was programmed between 180 and $230^{\circ}$ and the flow rate of the $\mathrm{N}_{2}$ carrier gas was $4.5 \mathrm{ml} / \mathrm{min}$. The peaks obtained were identified by 
comparison of retention times with those of known standards under identical operating conditions.

$T G$, total cholesterol $(T C)$ and high-density-lipoprotein $(H D L)$-cholesterol analysis

TG and TC in serum were determined by enzymic methods (Boehringer Mannheim) using a PA 800 programmable analyser (Vitatron) and test kits TC 701912 and TG 166588. HDL-cholesterol was analysed after precipitation of very-low-density lipoproteins (VLDL) and low-density lipoproteins (LDL) (Bio Merieux, Marcy l'Etoile, 69260 Charbonnièresles-Bains, France) HDL-Cholesterol-Phospho Kit, cat. no. 61531).

\section{Histological examination of adipose tissue}

Epididymal adipose tissue samples were taken from eight animals of the FO 1 (no supplementation) and 4 (highest supplementation), LN 1 and 4 and SF 1 and 4 groups. The samples were fixed in $100 \mathrm{ml} / 1$ neutral buffered formalin and embedded in paraplast for histopathological study. Sections were cut at $4 \mu \mathrm{m}$ and stained with haematoxylin and azophloxin. Unstained sections were embedded in fluoromount and studied under a fluorescence microscope for detection of lipofuscin. The microscope was equipped with a Zeiss incident-light fluorescence set-up, using a HBO-50W lamp as a light source and a vertical illuminator III RS with the combined filters BP 485, FT 510 and LP 515.

\section{Statistical analysis}

The relationship between dietary $\alpha$-tocopherol and liver or serum $\alpha$-tocopherol was investigated using linear regression analysis. The following model was found to provide a good fit to the data: $Y=a+b_{i}+c$ TE +error, where $Y$ is log liver or serum $\alpha$-tocopherol concentration, TE is $\log$ dietary tocopherol equivalents and $b_{i}$ is a constant factor for each of three dietary fats (SF, LN or FO). The non-supplemented groups were analysed by analysis of variance. The Tukey multiple range test was used to test for differences between the various groups. Differences of $P<0.05$ were considered to be significant. The data of serum and liver $\alpha$-tocopherol levels were log transformed before analysis to obtain equal variances. The relationship between serum and liver $\alpha$-tocopherol levels was investigated using Pearson's correlation coefficient.

\section{RESULTS}

Serum $\alpha$ - and $\gamma$-tocopherol concentrations (Table 2)

During the experimental period (days 24, 52 and 76) the serum $\alpha$-tocopherol concentrations within each group did not change. The four groups on each of the high-PUFA diets showed a clear dose-response of dietary vitamin $\mathrm{E}$ to serum tocopherol; with increasing dietary vitamin $E$ levels an increase in serum $\alpha$-tocopherol and a decrease in serum $\gamma$-tocopherol were found. The level of serum $\alpha$-tocopherol was also dependent on the type of dietary fat. Of the non-supplemented groups the serum $\alpha$-tocopherol levels of animals on the control diets (CO 1, CO 2) and those on the linoleic acid rich diet (SF 1) did not differ significantly. The animals given the LN diet had a lower serum $\alpha$-tocopherol concentration compared with those of the SF group and the control groups. The animals on the FO diet had lower serum $\alpha$-tocopherol levels than all other experimental groups. The relationship between dietary TE and serum $\alpha$-tocopherol is given by the equation:

$$
\log \text { serum } \alpha \text {-tocopherol }=0 \cdot 762+b_{i}+0 \cdot 426 \log \text { TE }
$$

(residual standard deviation (RSD) $0.077, r^{2} 0.86, P<0.0001$ ), where $b_{i}=0$ for the SF groups, $b_{i}=-0.110$ for the LN groups and $b_{i}=-0.461$ for the FO groups.

The regression lines of the serum $\alpha$-tocopherol concentrations (day 76) showed that only for the FO groups were the levels of dietary supplementation with vitamin $\mathrm{E}$ insufficient to 
Table 2. $\alpha$ - and $\gamma$-tocopherol concentrations in the serum of rats on days 24,52 and 76 on highpolyunsaturated fatty acid diets (high in fish oil $(F O)$, linseed oil (LN) or sunflower-seed oil $(S F)$ ) supplemented with graded levels of $D L-\alpha$-tocopheryl acetate, and on control diets (rich in monounsaturated fatty acids (CO 1) or saturated fatty acids and dienoic acids (CO 2))

(Mean values with their standard errors for eight to sixteen rats)

\begin{tabular}{|c|c|c|c|c|c|c|c|c|c|c|c|c|}
\hline \multirow{3}{*}{$\begin{array}{l}\text { Experimental } \\
\text { group }\end{array}$} & \multicolumn{6}{|c|}{ Serum $\alpha$-tocopherol $(\mu \mathrm{g} / \mathrm{ml}) \S$} & \multicolumn{6}{|c|}{ Serum $\gamma$-tocopherol $(\mu \mathrm{g} / \mathrm{ml})^{l}$} \\
\hline & \multicolumn{2}{|c|}{ Day 24} & \multicolumn{2}{|c|}{ Day 52} & \multicolumn{2}{|c|}{ Day 76} & \multicolumn{2}{|c|}{ Day 24} & \multicolumn{2}{|c|}{ Day 52} & \multicolumn{2}{|c|}{ Day 76} \\
\hline & Mean & $\overline{\text { SEM }}$ & Mean & SEM & Mean & SEM & Mean & SEM & Mean & SEM & Mean & SEM \\
\hline FO $1 *$ & $5 \cdot 6^{\mathrm{a}}$ & 0.2 & $4.9^{\mathrm{a}}$ & 0.3 & $5 \cdot 1^{a}$ & 0.3 & 0.3 & $0 \cdot 1$ & $0 \cdot 3$ & 0.04 & 0.3 & 0.02 \\
\hline $\mathrm{FO} 2^{*}$ & $7 \cdot 1$ & 0.4 & $7 \cdot 3$ & 0.4 & $7 \cdot 8$ & 0.3 & ND & - & $0 \cdot 1$ & 0.04 & 0.2 & 0.03 \\
\hline FO $3^{*}$ & $8 \cdot 8$ & 0.6 & $8 \cdot 1$ & 0.5 & $8 \cdot 3$ & 0.6 & ND & - & ND & - & 0.1 & 0.04 \\
\hline FO $4 *$ & $9 \cdot 4$ & 0.6 & 8.9 & 0.5 & $10 \cdot 0$ & 0.6 & ND & - & ND & - & ND & - \\
\hline LN $1 *$ & $11 \cdot 0^{\mathrm{b}}$ & 0.8 & $11 \cdot 1^{b}$ & 1.0 & $12 \cdot 5^{b}$ & $1 \cdot 2$ & $1 \cdot 0$ & $0 \cdot 1$ & $1 \cdot 1$ & 0.2 & 1.5 & 0.2 \\
\hline LN 2* & $13 \cdot 2$ & 0.7 & $12 \cdot 2$ & 0.8 & $15 \cdot 1$ & 0.7 & 0.6 & $0 \cdot 1$ & 0.5 & 0.1 & 0.5 & 0.02 \\
\hline LN 3* & $14 \cdot 6$ & $1 \cdot 0$ & 13.6 & 0.9 & $15 \cdot 6$ & 0.7 & 0.4 & $0 \cdot 1$ & 0.2 & 0.04 & 0.3 & 0.03 \\
\hline LN 4* & $16 \cdot 1$ & $1 \cdot 3$ & $16 \cdot 1$ & 0.2 & 19.9 & $2 \cdot 6$ & 0.2 & $0 \cdot 1$ & 0.2 & 0 & 0.2 & 0.1 \\
\hline SF $1 *$ & $14 \cdot 9^{\mathrm{c}}$ & 0.6 & $13 \cdot 8^{\mathrm{c}}$ & 0.7 & $15 \cdot 5^{\mathrm{c}}$ & 0.5 & 1.7 & $0 \cdot 1$ & $1 \cdot 5$ & 0.1 & 1.7 & 0.1 \\
\hline SF $2^{*}$ & $17 \cdot 6$ & 0.6 & $17 \cdot 4$ & 0.7 & $19 \cdot 5$ & 1.0 & $1 \cdot 2$ & 0.1 & $1 \cdot 1$ & 0.1 & $1 \cdot 3$ & $0 \cdot 1$ \\
\hline SF $3^{*}$ & $20 \cdot 0$ & $1 \cdot 1$ & $19 \cdot 6$ & 1.0 & $19 \cdot 6$ & 0.7 & 0.5 & $0 \cdot 1$ & 1.0 & $0 \cdot 1$ & 0.9 & 0.1 \\
\hline SF $4^{*}$ & $20 \cdot 6$ & $1 \cdot 2$ & $19 \cdot 1$ & $1 \cdot 1$ & $21 \cdot 5$ & $1 \cdot 1$ & 0.8 & $0 \cdot 1$ & 0.6 & 0.1 & 0.8 & $0 \cdot 1$ \\
\hline $\mathrm{COI} \dagger$ & $17 \cdot 0^{\circ}$ & 0.6 & $16 \cdot 2^{x} t$ & 0.5 & $17 \cdot 4^{\mathrm{e}}$ & 0.6 & 1.9 & 0.1 & $1 \cdot 2$ & $0 \cdot 1$ & $1 \cdot 8$ & 0.2 \\
\hline $\mathrm{COII} \dagger$ & $17 \cdot 0^{e}$ & 0.4 & $15 \cdot 4^{c}$ & 0.4 & $16 \cdot 2^{c}$ & 0.5 & $2 \cdot 1$ & $0 \cdot 1$ & $1 \cdot 4$ & $0 \cdot 1$ & 1.7 & 0.1 \\
\hline
\end{tabular}

ND, none detectable (detection limit $<0.05 \mu \mathrm{g} / \mathrm{ml}$.

a. b, c Means in one column bearing the same superscript letter are not significantly different at $P<0.05$.

* Mean value for eight animals.

$\dagger$ Mean value for sixteen animals.

Mean value for fifteen animals.

$\S$ Division by 430.69 gives $\mu \mathrm{mol} / \mathrm{ml}$.

II Division by 416.66 gives $\mu \mathrm{mol} / \mathrm{ml}$.

$\S$ For details of diets and procedures, see pp. $128-131$.

reach the serum $\alpha$-tocopherol levels of the control groups (Fig. 1). Serum $\gamma$-tocopherol was below the detection limit $(<0 \cdot 15 \mu \mathrm{g} / \mathrm{ml})$ in all supplemented FO groups on day 24 . On day 76 only the highest supplemented FO groups (FO 4) had serum $\gamma$-tocopherol levels below the detection limit. The type of dietary fat had comparable effects on serum levels of $\gamma$ tocopherol and $\alpha$-tocopherol.

\section{Serum TG concentration}

No influence of dietary vitamin $E$ on the serum TG concentration was observed. Therefore all means (non-supplemented and supplemented) of each high-PUFA group were pooled. On day 76 the levels of TG in the serum of the $\mathrm{CO} 2$ and SF groups were significantly lower than the serum TG levels of the CO 1 group (Table 3). The TG concentrations in the serum of the LN groups and FO groups were not significantly different from each other, but were lower than those of the SF and control groups.

Serum TC and HDL-cholesterol concentrations and HDL-cholesterol:TC ratio Serum TC and HDL-cholesterol levels of the animals given the FO 1 diets were significantly lower than the levels of those animals on the LN 1, SF 1, CO 1 and CO 2 diets (Table 4). The HDL-cholesterol:TC ratios were significantly higher in The FO 1 groups when compared with the LN 1, SF 1, CO 1 and $\mathrm{CO} 2$ groups, indicating that HDL-cholesterol 


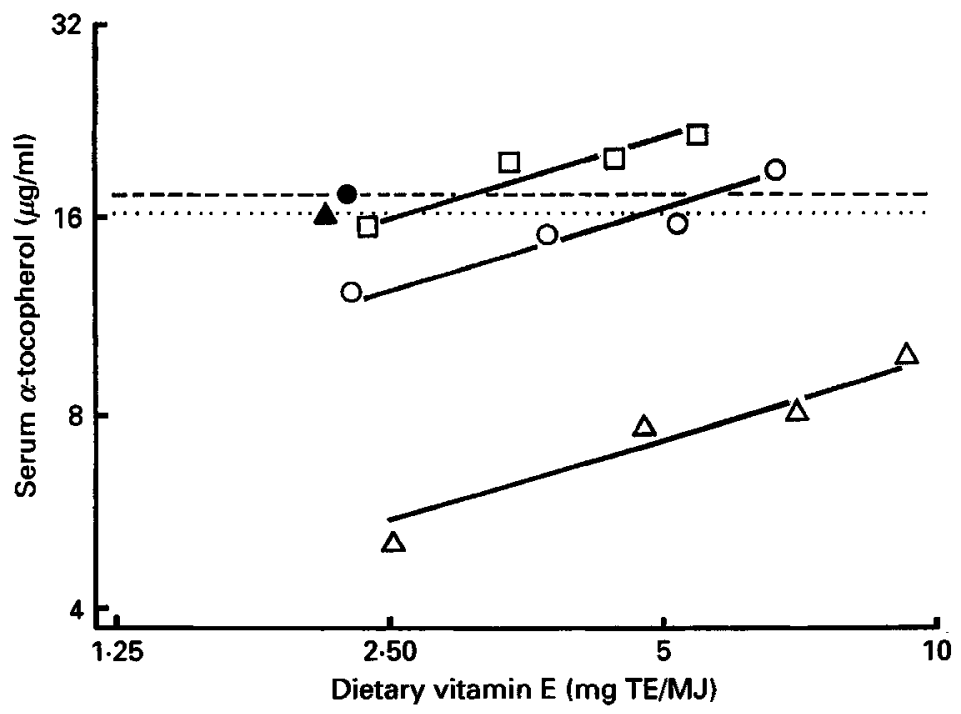

Fig. 1. Serum $\alpha$-tocopherol concentrations of rats fed on diets rich in polyenoic acids $(\Delta)$, trienoic acids $(O)$ or dienoic acids $(\square)$, with different concentrations of dietary vitamin $E$, and the corresponding calculated regression lines, compared with serum concentrations of rats fed on diets rich in either monounsaturated fatty acids (O) or saturated fatty acids and dienoic acids $(\boldsymbol{A})$ for a period of $76 \mathrm{~d}$. TE, tocopherol equivalents.

Table 3. Triacylglycerol concentration in the serum of rats on days 24, 52 and 76 on high polyunsaturated fatty acid diets (high in fish oil (FO), linseed oil (LN) or sunflower-seed oil $(S F)$ ) supplemented with graded levels of $D L-\alpha$-tocopheryl acetate and on control diets (rich in monounsaturated fatty acids (CO 1) or saturated fatty acids and dienoic acids (CO 2))*

(Mean values with their standard errors for eight to sixteen rats)

\begin{tabular}{|c|c|c|c|c|c|c|c|}
\hline \multirow{3}{*}{$\begin{array}{l}\text { Experimental } \\
\text { group }\end{array}$} & \multirow[b]{3}{*}{$n$} & \multicolumn{6}{|c|}{ Serum triacylglycerol $(\mathrm{mmol} / \mathrm{l})$} \\
\hline & & \multicolumn{2}{|c|}{ Day 24} & \multicolumn{2}{|c|}{ Day 52} & \multicolumn{2}{|c|}{ Day 76} \\
\hline & & Mean & SEM & Mean & SEM & Mean & SEM \\
\hline $\begin{array}{l}\text { FO } 1 \\
\text { FO } 2 \\
\text { FO } 3 \\
\text { FO } 4 \\
\text { Pooled }\end{array}$ & $\begin{array}{l}8 \\
8 \\
8 \\
8\end{array}$ & $\begin{array}{l}0.71 \\
0.73 \\
0.80 \\
0.75 \\
0.75^{\mathrm{a}}\end{array}$ & $\begin{array}{l}0.05 \\
0.11 \\
0.12 \\
0.08 \\
0.05\end{array}$ & $\begin{array}{l}1 \cdot 15 \\
1 \cdot 13 \\
0.77 \\
0.72 \\
0.94^{\mathrm{a}}\end{array}$ & $\begin{array}{l}0.15 \\
0.20 \\
0.05 \\
0.06 \\
0.07\end{array}$ & $\begin{array}{l}0.96 \\
1.08 \\
0.84 \\
0.79 \\
0.92^{\mathrm{a}}\end{array}$ & $\begin{array}{l}0.07 \\
0.15 \\
0 \cdot 11 \\
0 \cdot 12 \\
0 \cdot 06\end{array}$ \\
\hline $\begin{array}{l}\text { LN } 1 \\
\text { LN } 2 \\
\text { LN } 3 \\
\text { LN } 4 \\
\text { Pooled }\end{array}$ & $\begin{array}{l}8 \\
8 \\
8 \\
8\end{array}$ & $\begin{array}{l}1.53 \\
1.87 \\
1.47 \\
1.35 \\
1.55^{\mathrm{a}}\end{array}$ & $\begin{array}{l}0.18 \\
0.03 \\
0.23 \\
0.09 \\
0.11\end{array}$ & $\begin{array}{l}1 \cdot 41 \\
1 \cdot 15 \\
1 \cdot 24 \\
1 \cdot 10 \\
1 \cdot 22^{\mathrm{a}}\end{array}$ & $\begin{array}{l}0.17 \\
0.20 \\
0.17 \\
0.28 \\
0.10\end{array}$ & $\begin{array}{l}1 \cdot 37 \\
1 \cdot 23 \\
1 \cdot 23 \\
1 \cdot 23 \\
1 \cdot 26^{a}\end{array}$ & $\begin{array}{l}0 \cdot 15 \\
0 \cdot 20 \\
0 \cdot 22 \\
0 \cdot 24 \\
0 \cdot 10\end{array}$ \\
\hline $\begin{array}{l}\text { SF 1 } \\
\text { SF } 2 \\
\text { SF } 3 \\
\text { SF } 4 \\
\text { Pooled }\end{array}$ & $\begin{array}{l}8 \\
8 \\
8 \\
8\end{array}$ & $\begin{array}{l}2 \cdot 11 \\
2 \cdot 75 \\
2 \cdot 57 \\
3 \cdot 40 \\
2 \cdot 70^{b}\end{array}$ & $\begin{array}{l}0.37 \\
0.46 \\
0.26 \\
0.54 \\
0.22\end{array}$ & $\begin{array}{l}2 \cdot 20 \\
2 \cdot 16 \\
2 \cdot 59 \\
2 \cdot 65 \\
2 \cdot 40^{b}\end{array}$ & $\begin{array}{l}0 \cdot 34 \\
0 \cdot 27 \\
0 \cdot 43 \\
0 \cdot 40 \\
0 \cdot 18\end{array}$ & $\begin{array}{l}2 \cdot 11 \\
3 \cdot 21 \dagger \\
2 \cdot 52 \\
2 \cdot 93 \\
2 \cdot 68^{b}\end{array}$ & $\begin{array}{l}0.28 \\
0.61 \\
0.29 \\
0.46 \\
0.22\end{array}$ \\
\hline $\begin{array}{l}\mathrm{CO} 1 \\
\mathrm{CO} 2\end{array}$ & $\begin{array}{l}16 \\
16\end{array}$ & $\begin{array}{l}4 \cdot 48^{\mathrm{c}} \\
4 \cdot 14^{\mathrm{e}}\end{array}$ & $\begin{array}{l}0.63 \\
0.36\end{array}$ & $\begin{array}{l}3 \cdot 62^{\mathrm{c}} \\
2 \cdot 69^{\mathrm{c} . \mathrm{b}}\end{array}$ & $\begin{array}{l}0.55 \\
0.22\end{array}$ & $\begin{array}{l}4 \cdot 53^{\mathrm{c}} \\
2 \cdot 70^{\mathrm{b}}\end{array}$ & $\begin{array}{l}0.73 \\
0.19\end{array}$ \\
\hline
\end{tabular}

a, b,c Means in one column bearing the same superscript letter are not significantly different at $P<0.05$.

* For details of diets and procedures, see pp. 128-132.

+ Mean value for seven animals. 
Table 4. Total cholesterol (TC), high-density-lipoprotein-cholesterol (HDL-chol) and the $H D L$-chol: $T C$ ratio in the serum of rats fed on high-polyunsaturated fatty acid diets (high in fish oil $(F O)$, linseed oil $(L N)$ or sunflower-seed oil $(S F)$ ) supplemented with graded levels of $D L-\alpha$-tocopheryl acetate and on control diets (rich in monounsaturated fatty acids (CO 1) or saturated fatty acids and dienoic acids (CO 2))*

(Mean values with their standard errors for eight to sixteen rats)

\begin{tabular}{|c|c|c|c|c|c|c|c|}
\hline \multirow{2}{*}{$\begin{array}{l}\text { Experimental } \\
\text { group }\end{array}$} & \multirow[b]{2}{*}{$n$} & \multicolumn{2}{|c|}{$\begin{array}{c}\mathrm{TC} \\
(\mathrm{mmol} / \mathrm{l})\end{array}$} & \multicolumn{2}{|c|}{$\begin{array}{l}\text { HDL-chol } \\
(\mathrm{mmol} / \mathrm{l})\end{array}$} & \multicolumn{2}{|c|}{ HDL-chol: TC ratio } \\
\hline & & Mean & SEM & Mean & SEM & Mean & SEM \\
\hline FO 1 & 8 & $1 \cdot 46^{\mathrm{a}}$ & 0.04 & $1 \cdot 16^{\mathrm{a}}$ & 0.03 & $0 \cdot 79^{\mathrm{a}}$ & 0.03 \\
\hline FO 2 & 8 & 1.39 & 0.08 & 1.07 & 0.06 & 0.78 & 0.03 \\
\hline FO 3 & 8 & 1.42 & 0.05 & 1.02 & 0.04 & 0.72 & 0.02 \\
\hline FO 4 & 8 & 1.57 & 0.08 & $1 \cdot 15$ & 0.06 & 0.73 & 0.02 \\
\hline LN 1 & 8 & $2 \cdot 50^{\mathrm{b}}$ & $0 \cdot 25$ & $1 \cdot 63^{\mathbf{b}}$ & 0.20 & $0.65^{b}$ & 0.03 \\
\hline LN 2 & 8 & $2 \cdot 25$ & 0.09 & 1.49 & 0.11 & $0 \cdot 66$ & 0.03 \\
\hline LN 3 & 8 & $2 \cdot 19$ & 0.09 & 1.45 & 0.06 & 0.66 & 0.02 \\
\hline LN 4 & 8 & 2.45 & $0 \cdot 18$ & 1.69 & $0 \cdot 14$ & 0.68 & 0.01 \\
\hline SF 1 & 8 & $2 \cdot 60^{\mathrm{b}}$ & 0.11 & $1.60^{\mathrm{b}}$ & 0.09 & $0.61^{b}$ & 0.02 \\
\hline SF 2 & 8 & $2 \cdot 76$ & 0.10 & $1 \cdot 71$ & 0.11 & 0.62 & $0-02$ \\
\hline SF 3 & 8 & $2 \cdot 71$ & 0.08 & $1 \cdot 76$ & 0.09 & 0.65 & 0.02 \\
\hline SF 4 & 8 & $2 \cdot 53$ & 0.09 & $1 \cdot 57$ & 0.08 & 0.62 & 0.02 \\
\hline $\mathrm{CO}_{1}$ & 16 & $2.62^{b}$ & 0.07 & $1.60^{\mathrm{b}}$ & 0.07 & $0.61^{b}$ & 0.03 \\
\hline $\mathrm{CO} 2$ & 16 & $2 \cdot 64^{b}$ & 0.07 & $1.68^{\mathrm{b}}$ & 0.06 & $0 \cdot 64^{\mathrm{b}}$ & 0.02 \\
\hline
\end{tabular}

a.b.e Means (of the non-supplemented group) in one column bearing the same superscript letter are not significantly different at $P<0.05$.

* For details of diets and procedures, see pp. 128-132.

contributed relatively more to serum TC of the animals on the FO diet. No influence of dietary vitamin E on serum TC concentrations was observed.

\section{Liver $\alpha$ - and $\gamma$-tocopherol concentrations}

The four groups on each of the high-PUFA diets showed clear dose-response relationships between dietary vitamin $E$ and liver $\alpha$-tocopherol (Table 5); with increasing levels of dietary vitamin $\mathrm{E}$ an increase in liver $\alpha$-tocopherol was found. Taking only the non-supplemented groups into consideration, no significant difference between the liver $\alpha$-tocopherol levels of the CO 2 and the high linoleic acid group (SF 1) was found. The liver $\alpha$-tocopherol concentration of the animals of group $\mathrm{CO} 1$ was significantly higher, whereas the levels of the LN and FO groups were significantly lower than the liver $\alpha$-tocopherol levels found for the SF and CO 2 groups. The liver $\alpha$-tocopherol levels of the non-supplemented FO group were lower than those of all other groups.

The relationship between dietary vitamin $\mathrm{E}$ and liver $\alpha$-tocopherol levels is given by the equation:

$$
\log \text { liver } \alpha \text {-tocopherol }=0.528+b_{i}+0.864 \log \text { TE }
$$

(RSD $0.067, r^{2} 0.86, P<0.0001$ ), where $b_{i}=0$ for the SF groups, $b_{i}=-0.035$ for the LN groups and $b_{i}=-0.224$ for the FO groups.

The regression lines of the liver $\alpha$-tocopherol concentrations of the PUFA groups showed that the levels of vitamin E supplementation were sufficient to reach the liver $\alpha$ tocopherol levels of the control groups (Fig. 2). The $\gamma$-tocopherol concentration in the livers (Table 5) of the animals given diets rich in fish oil was below determination limit. The 
Table 5. $\alpha$-and $\gamma$-tocopherol concentrations in the liver of rats fed on high-polyunsaturated fatty acid diets (high in fish oil (FO), linseed oil $(L N)$ or sunflower-seed oil $(S F)$ ) supplemented with graded levels of $D L-\alpha$-tocopheryl acetate and on control diets (rich in monounsaturated fatty acids ( $\mathrm{CO} 1$ ) or saturated fatty acids and dienoic acids (CO 2))*

(Mean values with their standard errors for eight to sixteen rats)

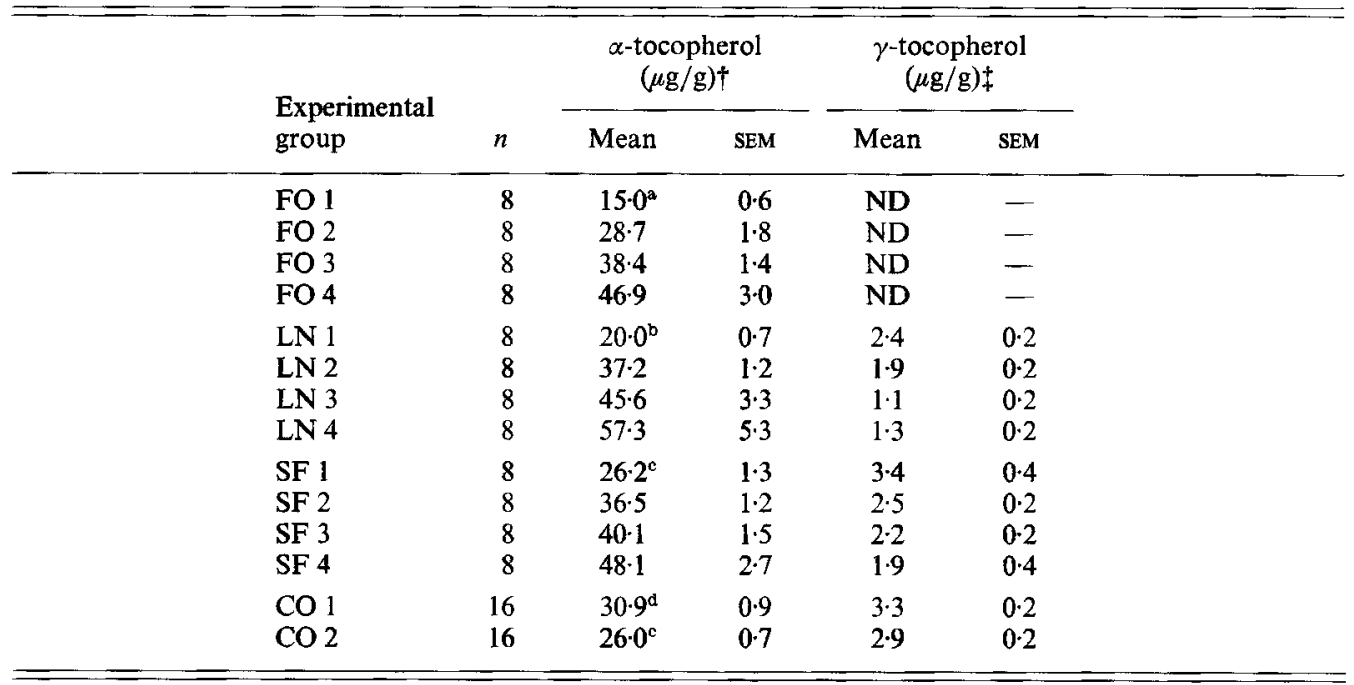

ND, none detectable (determination limit $<0.15 \mu \mathrm{g} / \mathrm{g}$ ).

a.b,e, a Means in one column bearing the same superscript letter are not significantly different at $P<0.05$.

* For details of diets and procedures, see pp. 128-131.

$\dagger$ Division by 430.69 gives $\mu \mathrm{mol} / \mathrm{g}$.

$\ddagger$ Division by 416.66 gives $\mu \mathrm{mol} / \mathrm{g}$.

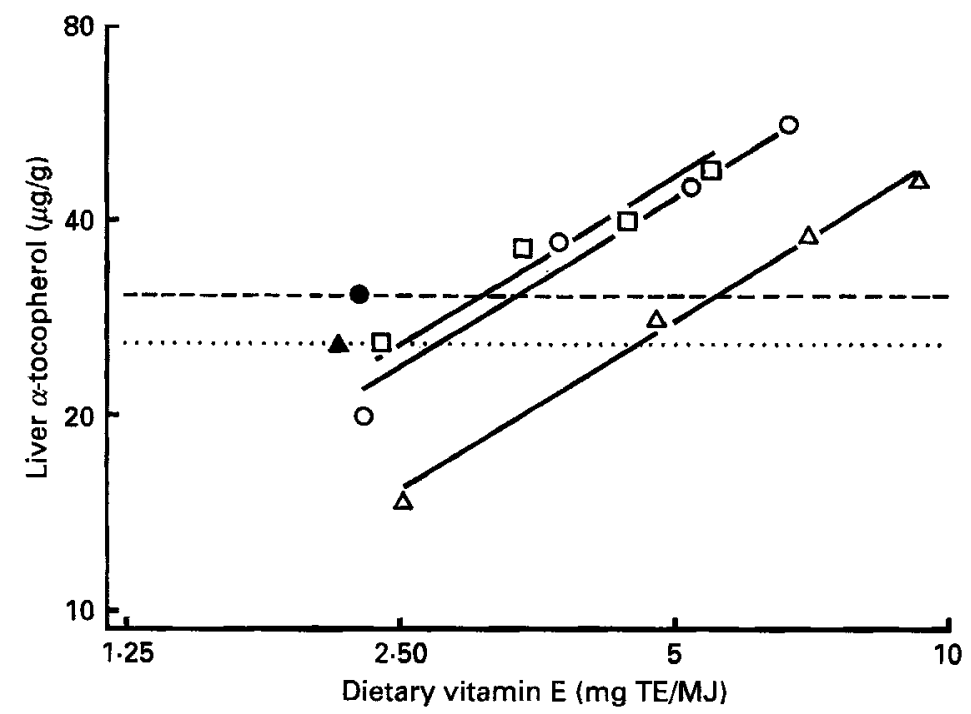

Fig. 2. Liver $\alpha$-tocopherol concentrations of rats fed on diets rich in polyenoic acids $(\triangle)$, trienoic acids $(O)$ or dienoic acids $(\square)$, with different concentrations of dietary vitamin $E$ and the corresponding calculated regression lines, compared with serum concentrations of rats fed on diets rich in either monounsaturated fatty acids $(\bullet)$ or saturated fatty acids and dienoic acids $(\boldsymbol{\Lambda})$ for a period of $76 \mathrm{~d}$. TE, tocopherol equivalents. 
Table 6. Fatty acid composition of liver triacylglycerols $(T G)$ and phospholipids $(P L)$ of rats fed on high-polyunsaturated fatty acid diets (high in fish oil (FO), linseed oil ( $L N)$ or sunflower-seed oil $(S F)$ ) either not supplemented $(I)$ or supplemented with the highest investigated level of $D L-\alpha$-tocopheryl acetate (4) and on control diets (rich in monounsaturated fatty acids (CO 1) or saturated fatty acids and dienoic acids (CO 2))*

(Mean values with their standard errors for four rats)

\begin{tabular}{|c|c|c|c|c|c|c|c|c|}
\hline \multirow[b]{2}{*}{ Dietary group... } & \multicolumn{8}{|c|}{ Fatty acid composition ( $\mathrm{g} / 100 \mathrm{~g}$ fatty acids) } \\
\hline & FO 1 & FO 4 & LN 1 & LN 4 & SF 1 & SF 4 & $\mathrm{CO} 1$ & $\mathrm{CO} 2$ \\
\hline \multicolumn{9}{|l|}{ Liver TG } \\
\hline Saturated & 22.9 & $19 \cdot 2$ & $26 \cdot 0$ & $25 \cdot 7$ & $27 \cdot 6$ & $27 \cdot 6$ & $28 \cdot 0$ & $30 \cdot 8$ \\
\hline Monoeic & $28 \cdot 6$ & $26 \cdot 7$ & $36 \cdot 3$ & $35 \cdot 0$ & $30 \cdot 6$ & $28 \cdot 3$ & $61 \cdot 5$ & $35 \cdot 1$ \\
\hline Dienoic $(18: 2 n-6)$ & $6 \cdot 1$ & $6 \cdot 4$ & $10 \cdot 8$ & 10.8 & $29 \cdot 9$ & $29 \cdot 9$ & 6.0 & 19.9 \\
\hline Trienoic $(18: 3 n-3 / n-6,20: 3 n-6 / n-9)$ & $1 \cdot 2$ & 1.5 & 13.2 & 14.7 & $1 \cdot 5$ & $1 \cdot 2$ & 0.7 & $2 \cdot 1$ \\
\hline Tetraenoic $(20: 4 n-6,22: 4 n-6)$ & $1 \cdot 0$ & $1 \cdot 1$ & 0.4 & 0.4 & $6 \cdot 9$ & $7 \cdot 3$ & 0.9 & $5 \cdot 4$ \\
\hline Pentaenoic $(20: 5 n-3,22: 5 n-3 / n-6)$ & $18 \cdot 6$ & $20 \cdot 7$ & $8 \cdot 0$ & $8 \cdot 2$ & $1 \cdot 4$ & $1 \cdot 3$ & 0.2 & $1 \cdot 4$ \\
\hline Hexaenoic $(22: 6 n-3)$ & $15 \cdot 8$ & $19 \cdot 4$ & $2 \cdot 9$ & $2 \cdot 6$ & $0 \cdot 1$ & 0.0 & $0 \cdot 1$ & $0 \cdot 1$ \\
\hline \multicolumn{9}{|l|}{ Liver PL } \\
\hline Saturated & $43 \cdot 8$ & $42 \cdot 9$ & $45 \cdot 4$ & $45 \cdot 1$ & $44 \cdot 6$ & $44 \cdot 6$ & $44 \cdot 5$ & $45 \cdot 0$ \\
\hline Monoeic & $8 \cdot 1$ & $9 \cdot 2$ & $6 \cdot 1$ & $6 \cdot 7$ & 4.0 & $4 \cdot 2$ & 8.5 & 4.9 \\
\hline Dienoic $(18: 2 n-6)$ & $3 \cdot 6$ & $3 \cdot 4$ & 11.9 & $12 \cdot 1$ & $11 \cdot 0$ & $11 \cdot 9$ & $6 \cdot 6$ & $10 \cdot 4$ \\
\hline Trienoic $(18: 3 n-3 / n-6,20: 3 n-6 / n-9)$ & $1 \cdot 0$ & 0.9 & $2 \cdot 1$ & $2 \cdot 2$ & 0.5 & 0.6 & 1.5 & 0.6 \\
\hline Tetraenoic $(20: 4 n-6,22: 4 n-6)$ & $15 \cdot 5$ & $16 \cdot 1$ & $14 \cdot 8$ & $14 \cdot 0$ & $34 \cdot 4$ & $34 \cdot 2$ & $31 \cdot 7$ & $34 \cdot 1$ \\
\hline Pentaenoic $(20: 5 n-3,22: 5 n-3 / n-6)$ & $11 \cdot 1$ & $10 \cdot 9$ & $10 \cdot 5$ & $11 \cdot 8$ & $3 \cdot 3$ & $3 \cdot 1$ & $2 \cdot 2$ & 3.6 \\
\hline Hexaenoic $(22: 6 n-3)$ & 13.5 & $14 \cdot 1$ & $8 \cdot 6$ & $7 \cdot 5$ & 1.7 & $1 \cdot 2$ & $5 \cdot 0$ & $1 \cdot 2$ \\
\hline
\end{tabular}

* For details of diets and procedures, see pp. 128-131.

level of $\gamma$-tocopherol in the livers of the LN and SF groups decreased with increasing levels of DL- $\alpha$-tocopheryl acetate supplementation. Furthermore, the liver $\gamma$-tocopherol concentrations of animals given the LN diets were significantly lower than those of the SF 1 group.

Fatty acid composition of liver $T G$ and $P L$

The fatty acid composition of the liver TG of four animals of the non-supplemented (FO 1, LN 1, SF 1, CO 1, CO 2) and that of the highest supplemented (FO 4, LN 4, SF 4) groups were analysed (Table 6). A slightly higher percentage of hexaenoic fatty acids (not significant at $P=0 \cdot 14$ ) in exchange for SAFA and MUFA was only found in the liver TG of the animals receiving the highest level of DL- $\alpha$-tocopheryl acetate supplementation (FO 4), when compared with the non-supplemented group. This influence was not observed in the other high-PUFA groups. The fatty acid composition of the TG reflected to a large extent the type of dietary fat given. Furthermore, the liver TG of the CO 2, SF 1 and SF 4 groups contained the highest percentage of the fatty acid 20:4, the elongation and desaturation product of $18: 2$. The $\mathbf{L N}$ groups had the highest concentration of trienoic acids $(18: 3 n-3)$ and transformation products ( $n-3$ fatty acids with more than four double bonds) and also a relatively high percentage of dienoic acids (18:2) compared with the $\mathrm{CO} 1$ group, taking the dietary intake of $3.9 \%$ energy as dietary dienoic acid into consideration.

The fatty acid composition of the liver PL was not influenced by the dietary vitamin E level in any of the groups (Table 6). The PL of the animals on the FO diet had the lowest dienoic acid concentration and the highest concentration of fatty acids with more than four double bonds. The concentration of fatty acids with four double bonds (mainly 20:4) was lower in the FO and LN groups than in the SD, $\mathrm{CO} 1$ and $\mathrm{CO} 2$ groups. An increase in 
Table 7. Body weights of rats on days 21,49 and 76 on high-polyunsaturated fatty acid diets (rich in fish oil $(F O)$, sunflower-seed oil $(S F)$ or linseed oil $(L N)$ supplemented with graded levels of $D L-\alpha$-tocopheryl acetate and on control diets (rich in monounsaturated fatty acids (CO 1) or saturated fatty acids and dienoic acids (CO 2))*

(Mean values with their standard errors for eight or sixteen rats)

\begin{tabular}{|c|c|c|c|c|c|c|c|}
\hline \multirow{3}{*}{$\begin{array}{l}\text { Experimental } \\
\text { group }\end{array}$} & \multirow[b]{3}{*}{$n$} & \multicolumn{6}{|c|}{ Body wt (g) } \\
\hline & & \multicolumn{2}{|c|}{ Day 21} & \multicolumn{2}{|c|}{ Day 49} & \multicolumn{2}{|c|}{ Day 76} \\
\hline & & Mean & SEM & Mean & SEM & Mean & SEM \\
\hline $\begin{array}{l}\text { FO 1 } \\
\text { FO } 2 \\
\text { FO 3 } \\
\text { FO } 4\end{array}$ & $\begin{array}{l}8 \\
8 \\
8 \\
8\end{array}$ & $\begin{array}{l}177 \cdot 0 \\
177 \cdot 4 \\
175 \cdot 6 \\
171 \cdot 4\end{array}$ & $\begin{array}{l}7 \cdot 2 \\
6 \cdot 2 \\
5 \cdot 1 \\
7 \cdot 4\end{array}$ & $\begin{array}{l}301 \cdot 5 \\
310 \cdot 5 \\
293 \cdot 2 \\
294 \cdot 9\end{array}$ & $\begin{array}{r}12 \cdot 2 \\
5 \cdot 0 \\
7 \cdot 4 \\
11 \cdot 8\end{array}$ & $\begin{array}{l}379.5 \\
384.9 \\
362.2 \\
366.6\end{array}$ & $\begin{array}{r}15 \cdot 2 \\
9.5 \\
8.9 \\
15.8\end{array}$ \\
\hline $\begin{array}{l}\text { LN } 1 \\
\text { LN } 2 \\
\text { LN } 3 \\
\text { LN } 4\end{array}$ & $\begin{array}{l}8 \\
8 \\
8 \\
8\end{array}$ & $\begin{array}{l}183.0 \\
179.7 \\
171.2 \\
183.4\end{array}$ & $\begin{array}{l}3.0 \\
4.8 \\
6.1 \\
4.5\end{array}$ & $\begin{array}{l}307.5 \\
299 \cdot 9 \\
280 \cdot 4 \\
293 \cdot 1\end{array}$ & $\begin{array}{r}5.1 \\
8.2 \\
10.7 \\
10.6\end{array}$ & $\begin{array}{l}373.4 \\
369 \cdot 0 \\
342 \cdot 0 \\
351 \cdot 7\end{array}$ & $\begin{array}{r}7 \cdot 9 \\
9 \cdot 3 \\
13 \cdot 3 \\
12 \cdot 6\end{array}$ \\
\hline $\begin{array}{l}\text { SF } 1 \\
\text { SF } 2 \\
\text { SF } 3 \\
\text { SF } 4\end{array}$ & $\begin{array}{l}8 \\
8 \\
8 \\
8\end{array}$ & $\begin{array}{l}174 \cdot 6 \\
187 \cdot 5 \\
185 \cdot 4 \\
174 \cdot 8\end{array}$ & $\begin{array}{l}6 \cdot 5 \\
4 \cdot 3 \\
3 \cdot 6 \\
7 \cdot 6\end{array}$ & $\begin{array}{l}280 \cdot 3 \\
312 \cdot 4 \\
303 \cdot 2 \\
282 \cdot 7\end{array}$ & $\begin{array}{r}10 \cdot 2 \\
3 \cdot 1 \\
6 \cdot 4 \\
9 \cdot 4\end{array}$ & $\begin{array}{l}338.3 \\
378.6 \\
365.0 \\
343.0\end{array}$ & $\begin{array}{r}10.9 \\
5.5 \\
9.3 \\
10.8\end{array}$ \\
\hline $\begin{array}{l}\mathrm{CO} 1 \\
\mathrm{CO} 2\end{array}$ & $\begin{array}{l}16 \\
16\end{array}$ & $\begin{array}{l}179.8 \\
182.0\end{array}$ & $\begin{array}{l}3.7 \\
4.2\end{array}$ & $\begin{array}{l}291.9 \\
296.0\end{array}$ & $\begin{array}{l}7.0 \\
6.1\end{array}$ & $\begin{array}{l}354 \cdot 1 \\
356 \cdot 4\end{array}$ & $\begin{array}{l}9 \cdot 1 \\
7 \cdot 9\end{array}$ \\
\hline
\end{tabular}

* For details of diets and procedures, see pp. 128-129.

the linoleic acid $(18: 2 n-6)$ intake (CO 1, CO 2 and SF) did not result in a significant increase in the $20: 4$ content of the PL. The major dietary fatty acid $(18: 3 n-3)$ of the LN groups was only represented by a relatively low percentage (about $2 \cdot 1 \%$ ) in the fatty acids of the PL, considering the $10 \%$ energy intake of $18: 3 n-3$, but was mainly recovered as elongation and desaturation products with more than four double bonds. Furthermore, dienoic acid was present in the LN group in an amount comparable with those of the SF and $\mathrm{CO} 2$ groups, even though the dietary intake was only $3.9 \%$ energy. Comparing the LN groups with the FO and $\mathrm{CO} 1$ groups, which all received comparable levels of dienoic acid in their diets, much higher concentrations of dienoic acid were found in the PL of the LN groups $(11.9 \%$ and $12.1 \%)$ than of the FO groups $(3.6 \%$ and $3.4 \%)$ and the $\mathrm{CO} 1$ group $(6.6 \%)$.

\section{Histological examination of adipose tissue}

The high-PUFA groups without (FO 1, SF 1, LN 1) and with the highest supplementation of DL- $\alpha$-tocopheryl acetate (FO 4, LN 4, SF 4) were examined for the occurrence of yellow fat disease (steatitis), a vitamin E deficiency symptom that occurs when diets are rich in fatty acids with three or more double bonds (Green \& Bunyan, 1969; Danse, 1989). In the FO group with the highest vitamin E supplementation, two animals showed the initial stage of yellow fat disease (stage $M$ steatitis) characterized by an interstitial accumulation of lipofuscin-loaded macrophages without degenerative changes in adipocytes (Plate 1; normal picture Plate 2). In four animals of this group a more progressed stage of this disorder was observed (stage $\mathrm{S}$ ) in which fat cells were affected and infiltrated by inflammatory cells (Plate 3). All animals of the non-supplemented FO group (FO 1) 
Table 8. Food consumption of rats on days 21,47 and 71 on high-polyunsaturated fatty acid diets (high in fish oil (FO), sunflower-seed oil (SF) or linseed oil (LN)) supplemented with graded levels of $D L-\alpha$-tocopheryl acetate and on control diets (rich in monounsaturated fatty acids (CO 1) or saturated fatty acids and dienoic acids (CO 2))*

(Mean values with their standard errors for eight or sixteen rats)

\begin{tabular}{|c|c|c|c|c|c|c|c|}
\hline \multirow{3}{*}{$\begin{array}{l}\text { Experimental } \\
\text { group }\end{array}$} & \multirow[b]{3}{*}{$n$} & \multicolumn{6}{|c|}{ Food consumption (g) } \\
\hline & & \multicolumn{2}{|c|}{ Day 21} & \multicolumn{2}{|c|}{ Day 47} & \multicolumn{2}{|c|}{ Day 71} \\
\hline & & Mean & SEM & Mean & SEM & Mean & SEM \\
\hline FO 1 & 8 & 13.7 & $1 \cdot 1$ & $14 \cdot 3$ & 0.7 & 14.9 & 0.5 \\
\hline $\mathrm{FO} 2$ & 8 & $10 \cdot 7$ & 1.6 & $14 \cdot 8$ & $0 \cdot 3$ & $15 \cdot 2$ & 0.7 \\
\hline FO 3 & 8 & $13 \cdot 0$ & 0.4 & $14 \cdot 0$ & 0.4 & $14 \cdot 6$ & $1 \cdot 0$ \\
\hline FO 4 & 8 & $12 \cdot 9$ & $0 \cdot 4$ & $15 \cdot 4$ & 0.6 & 15.6 & 0.5 \\
\hline LN 1 & 8 & $13-7$ & 0.6 & 14.6 & 0.3 & 14.8 & $0 \cdot 3$ \\
\hline LN 2 & 8 & $12 \cdot 9$ & 0.4 & $14 \cdot 3$ & 0.4 & 15.5 & 0.4 \\
\hline LN 3 & 8 & 12.9 & 0.7 & $14 \cdot 5$ & 0.5 & $14 \cdot 1$ & 0.5 \\
\hline LN 4 & 8 & $13 \cdot 6$ & 0.5 & $15 \cdot 1$ & 0.7 & $15 \cdot 7$ & 0.5 \\
\hline SF 1 & 8 & $13-5$ & 0.6 & $14 \cdot 1$ & 0.6 & $14 \cdot 4$ & 0.6 \\
\hline $\mathrm{SF} 2$ & 8 & $13 \cdot 4$ & 0.6 & $15 \cdot 1$ & 0.6 & 16.5 & 0.7 \\
\hline SF 3 & 8 & 13.5 & 0.4 & 14.5 & 0.5 & $14: 8$ & 0.7 \\
\hline SF 4 & 8 & $12 \cdot 8$ & 0.5 & 14.4 & 0.6 & $14 \cdot 5$ & 0.5 \\
\hline $\mathrm{CO} 1$ & 16 & 12.8 & 0.4 & 14.8 & 0.5 & 15.6 & 0.5 \\
\hline $\mathrm{CO} 2$ & 16 & $13 \cdot 2$ & $0 \cdot 4$ & 14.8 & 0.4 & $15 \cdot 9$ & 0.4 \\
\hline
\end{tabular}

* For details of diets and procedures, see pp. 128-129.

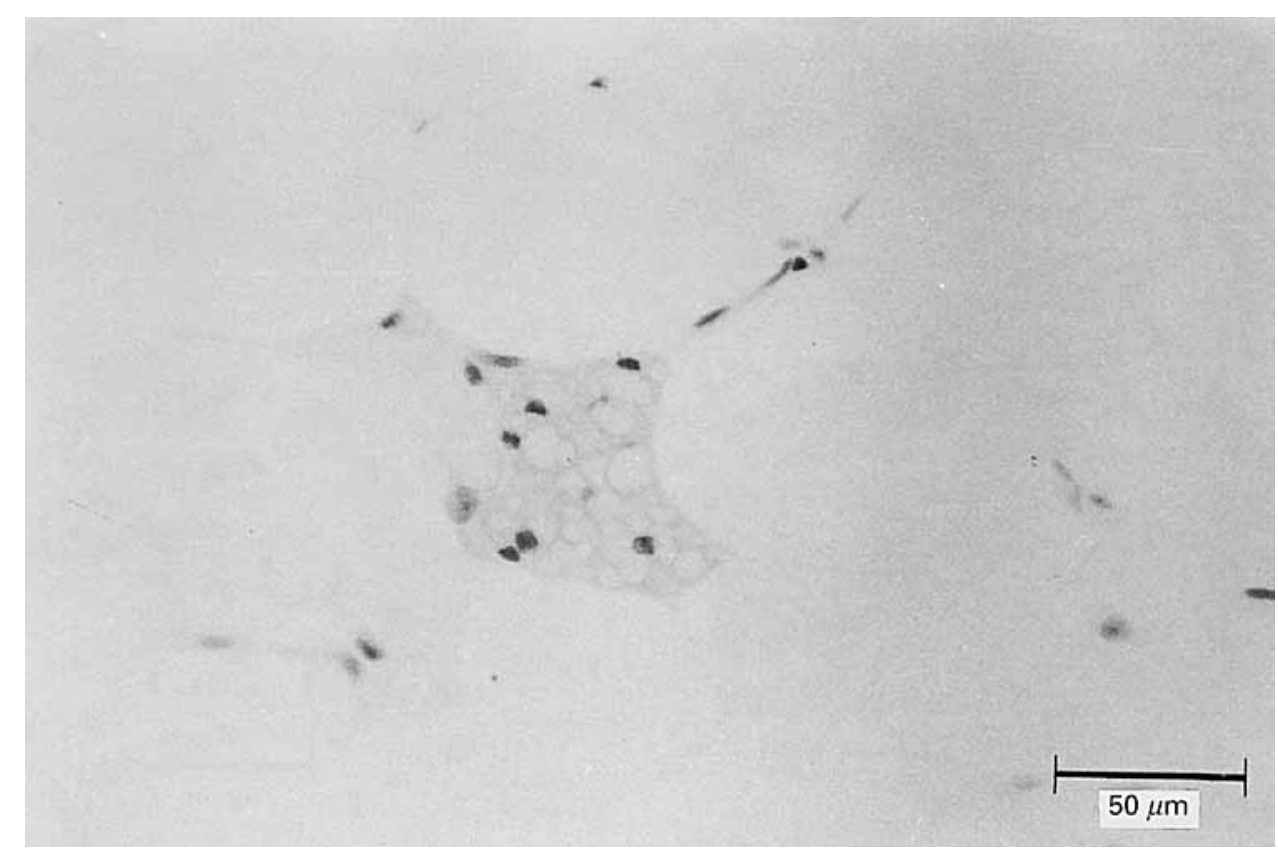

Plate 1. Stage-M steatitis. Initial stage, characterized by interstitial accumulation of lipofuscin-loaded macrophages, with affecting adipocytes (H.A. stain, $400 \times$ ). 


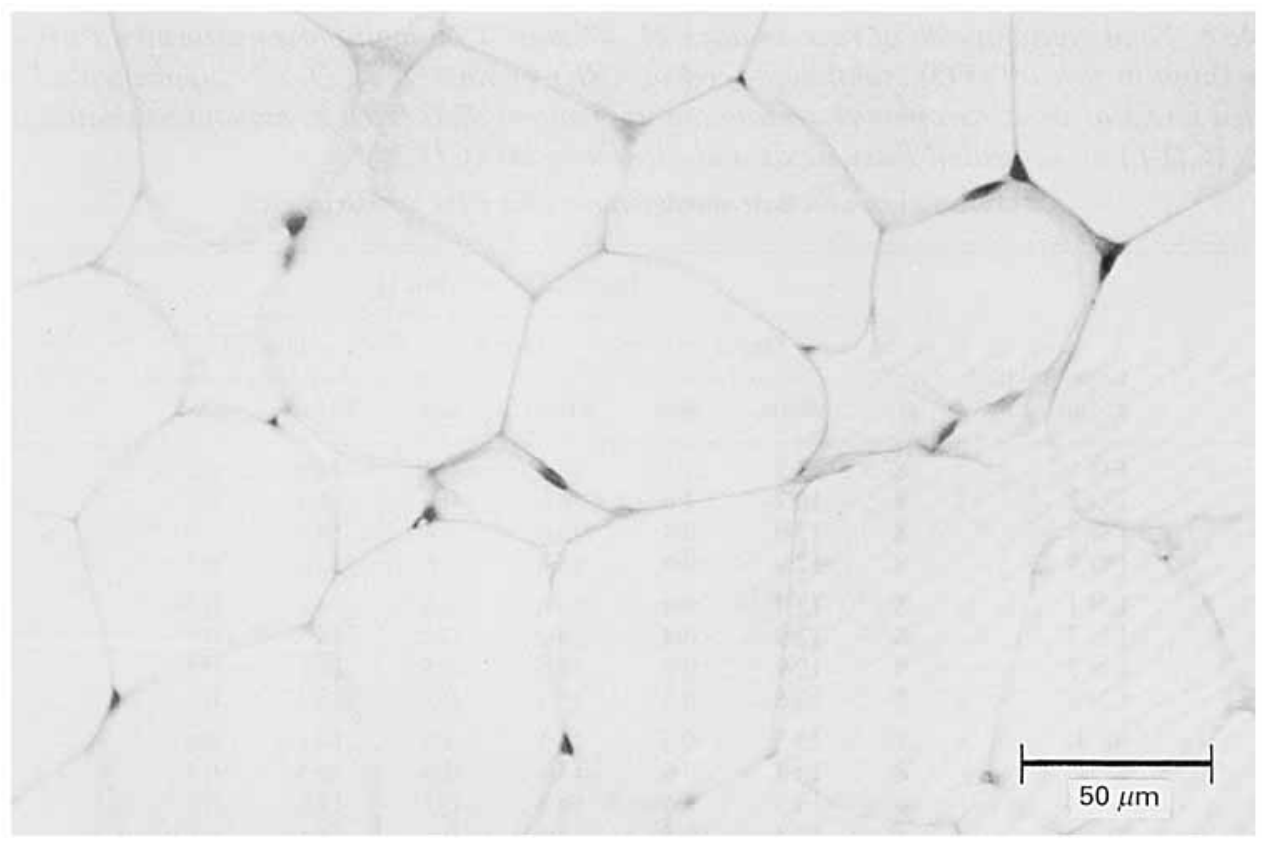

Plate 2. Normal adipose tissue. Typical adipocytes with a small rim of cytoplasm around fat vacuoles (H. A. stain, $400 \times$ ).

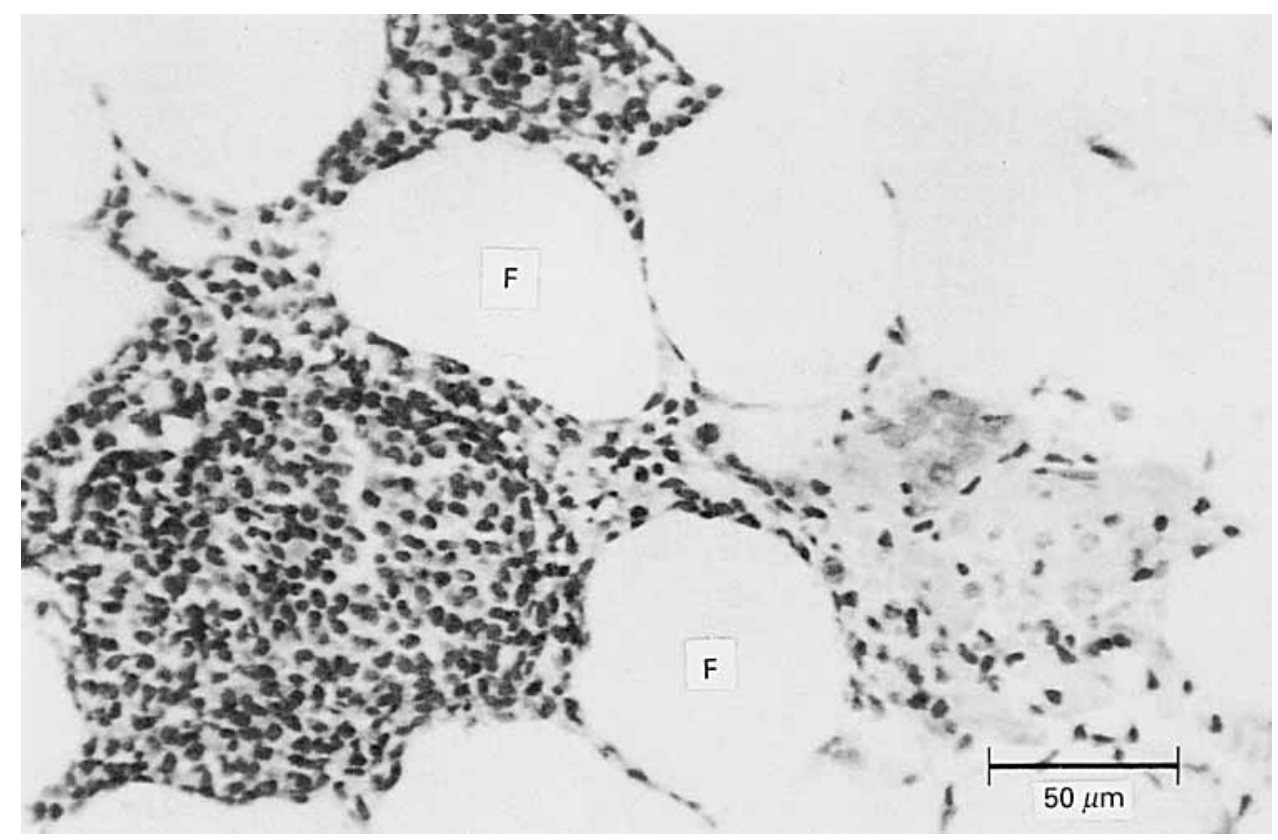

Plate 3. Stage-S steatitis. Affected fat cells (F) with infiltration of inflammatory cells such as macrophages and lymphocytes (H.A. stain, $400 \times$ ). 


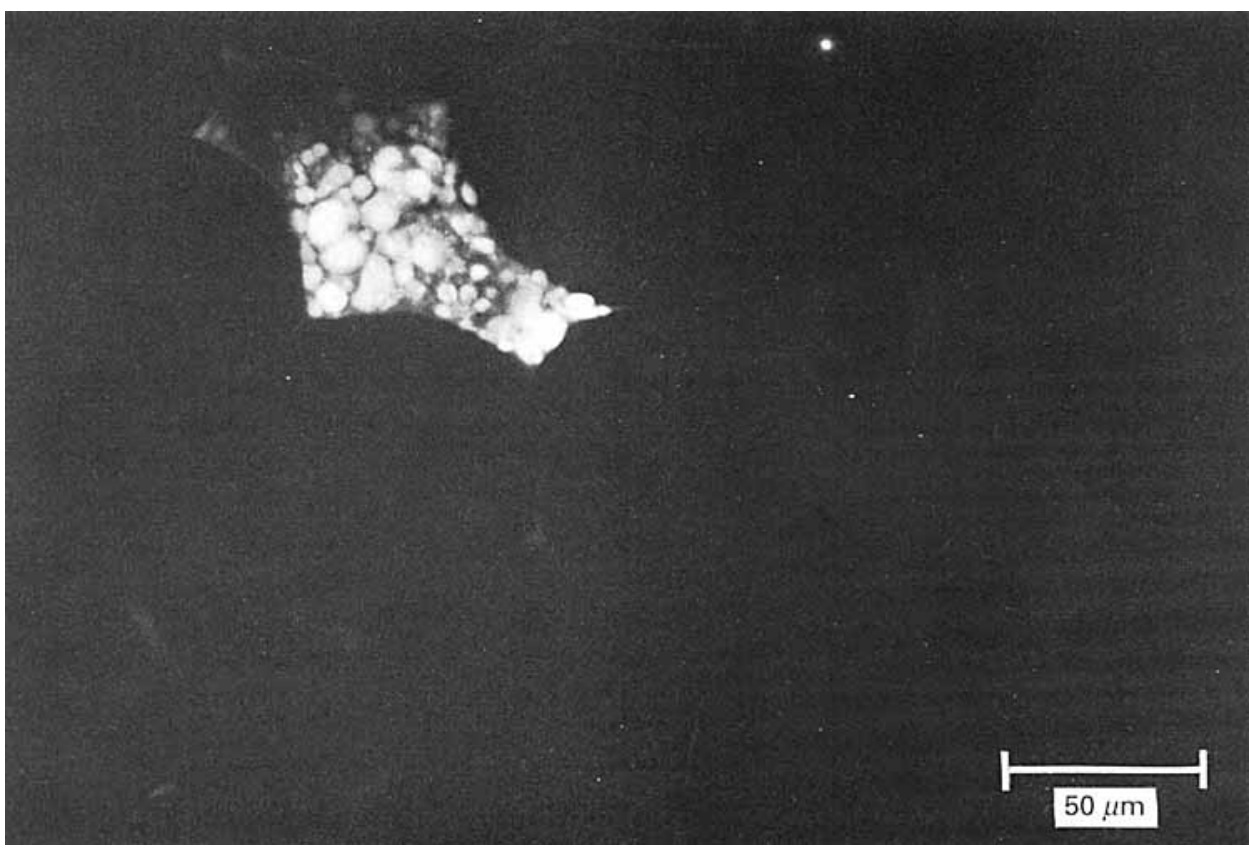

Plate 4. Stage-M steatitis. Autofluorescence of interstitial lipofuscin-laden macrophages (unstained section, $400 \times$ ).

showed stage $\mathrm{S}$ steatitis. In all affected animals of both groups positive fluorescence was observed, caused by lipofuscin-pigment being present in the affected adipose tissue (Plate 4). In one animal of the supplemented LN group stage $S$ steatitis was seen. In addition, in one animal of the non-supplemented SF group focal polymorphonuclear leucocyte infiltration in adipose tissue, not related to steatitis, was observed.

\section{DISCUSSION}

Defining reliable figures for a vitamin $E$ requirement is especially hampered by the fact that only limited information about the increased vitamin $\mathrm{E}$ requirement with different types and concentrations of PUFA in the diet is available. Only for linoleic acid have dose-response studies been performed (in animal models) showing that there is no linear relationship between linoleic acid intake and the vitamin $E$ requirement (Bieri \& Evarts, 1973; Jager, 1975). Some more recent animal studies (Mouri et al. 1984; Hirahara \& Kimura, 1987) show a clear decrease in the vitamin $E$ status in animals fed on diets containing marine oils. Usable information on the influence of dietary $\alpha$-linolenic acid on vitamin $\mathrm{E}$ status is lacking.

In the present study we investigated the effect of linoleic acid, linolenic acid and fish oil PUFA supplemented with graded levels of vitamin $E$ on the liver and serum tocopherol levels of rats. The liver has been chosen as the main indicator of vitamin $E$ status because this organ appears to respond (most) readily to dietary changes (Farrell, 1988).

Comparing the serum $\alpha$-tocopherol status of the groups on the high-PUFA diets and with different levels of dietary vitamin $\mathrm{E}$, a positive dose-response relationship was found, which was valid for the whole period of dietary treatment. When only the nonsupplemented, high-PUFA groups and the control groups are taken into consideration the 
serum $\alpha$-tocopherol levels of the control groups ( 3.0 and $8.5 \%$ energy as $18: 2$ respectively) and of the SF groups (13.2\% energy as $18: 2)$ were not significantly different, whereas the LN group (3.9\% energy as $18: 2,10 \%$ energy as $18: 3)$ had a significantly lower level and the FO group ( $3.2 \%$ energy as $18: 2,10 \%$ energy as fish oil PUFA) had the lowest levels. Even the FO subgroup with the highest DL- $\alpha$-tocopheryl acetate supplementation $(6.8 \mathrm{mg}$ TE added/MJ) did not reach the serum $\alpha$-tocopherol levels of the control groups. A complicating factor in the interpretation of differences in serum vitamin $\mathrm{E}$ concentration between the high-PUFA groups is the fact that serum vitamin $E$ is mainly carried by the lipoproteins which can be strongly influenced by the type of fat in the diet. Since in the rat HDL (Groot et al. 1988) is the main carrier of serum cholesterol, as well as of serum vitamin E (Bjorneboe et al. 1990), it seemed useful to correct for the change in the HDL concentration by using the vitamin E:HDL ratio in order to test whether this has a predictive value for liver vitamin $\mathrm{E}$ status. Taking all diets with different fat mixtures into consideration, regression analysis indicated that although a linear relationship exists between liver vitamin $E$ concentration and the serum $\alpha$-tocopherol:HDL ratio, the vitamin $\mathrm{E}: \mathrm{HDL}$ ratio is not a good predictor of liver tocopherol levels of individual animals (correlation coefficient 0.61). Regression analysis of the serum vitamin $\mathrm{E}: \mathrm{TC}$ ratio and the liver $\alpha$-tocopherol concentration resulted in a correlation coefficient of 0.79 , which is slightly better but still not acceptable as an estimator of liver tocopherol status.

Liver vitamin $\mathrm{E}$ status after $76 \mathrm{~d}$ on dietary treatment paralleled the trends seen in the serum concentrations. Liver $\alpha$-tocopherol concentration of the high-PUFA groups increased with increasing levels of dietary vitamin E (Fig. 2). In contrast to this, liver $\gamma$-tocopherol concentrations decreased with increasing dietary vitamin E levels. Serum $\gamma$-tocopherol showed the same response (Table 2). These findings are in accordance with the observations made by Handelman et al. (1985), who reported a decrease of plasma $\gamma$-tocopherol levels in humans after $\alpha$-tocopherol supplementation. Observations by Traber \& Kayden (1989) and Meydani et al. (1989) indicate that both $\alpha$ - and $\gamma$-tocopherol are equally well absorbed from the human intestine and secreted within chylomicrons, but the distribution of $\alpha$ - and $\gamma$-tocopherol within plasma lipoproteins differs.

In contrast to the findings in serum, liver $\alpha$-tocopherol concentrations of the supplemented FO groups reached the $\alpha$-tocopherol levels of the control groups. Referring only to the non-supplemented groups, liver vitamin E status of the CO 1 group (3\% energy as $18: 2,23.2 \%$ energy as MUFA) was the highest. Liver vitamin E concentrations of animals given $8.5 \%$ energy (CO 2) and $13.5 \%$ energy as linoleic acid (SF) were not significantly different at a confidence level of $P<0.05$, but were lower than those of the CO 1 group. From the equations describing the relationship between liver $\alpha$-tocopherol levels and dietary vitamin $\mathrm{E}$ in the high-PUFA groups and the regression lines illustrating this relationship, an obvious reduction of the liver $\alpha$-tocopherol status of the animals on the FO diet, compared with the animals on the SF and LN diets, was found.

From these results it can be concluded, that, if fatty acids with more than three double bonds are present in the diet in amounts of $10 \%$ energy, there is a clear extra vitamin $\mathrm{E}$ demand to build up the same liver $\alpha$-tocopherol concentrations as attained with fatty acids with fewer double bonds.

The analysis of the fatty acid composition of the liver PL showed that the amount and type of PUFA in the PL is strongly determined by the type of fat in the diet. Vitamin E supplementation did not influence the amount and type of PUFA in the PL. Liver PL of the animals on the FO diet contained the highest percentage of PUFA with more than four double bonds. An interesting observation was that in the LN groups and the SF groups comparable percentages of 18:2 were found, in spite of the fact that the LN diet contained only $3.9 \%$ energy as linoleic acid. This indicates a linoleic-acid-saving effect of $18: 3 n-3$, 


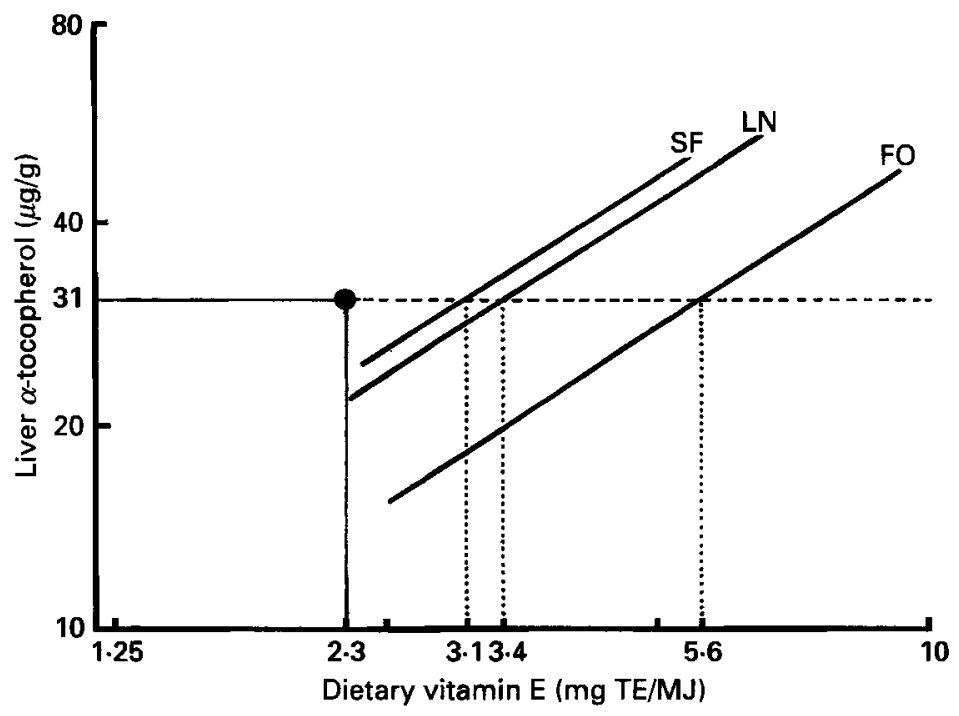

Fig. 3. Calculated regression lines of liver $\alpha$-tocopherol concentrations of rats fed on diets rich in polyenoic acids (FO), trienoic acids (LN) and dienoic acids (SF) and with different concentrations of dietary vitamin E. The liver $\alpha$-tocopherol status $(30 \mu \mathrm{g} / \mathrm{g})$ of rats fed on a diet rich in saturated fatty acids was used to calculate the absolute vitamin $E$ requirement of rats on the high polyunsaturated fatty acid diets to reach that level. TE, tocopherol equivalents.

probably caused by competition for the $\Delta$-6-desaturase (Kinsella, 1988), resulting in the lowest percentage of arachidonic acid $(20: 4)$ and a relatively high percentage of fatty acids with more than four double bonds in this group.

The fatty acid composition of the liver TG shows a higher percentage of PUFA in the high-PUFA groups. Whereas the SF groups showed the highest percentage of $18: 2$ in the liver TG, the LN diet had more 18:3n-3 and the FO groups had the highest percentage of PUFA with five and six double bonds. From an in vitro test (Holman, 1954) in which the susceptibility to peroxidation of fatty acids has been studied it is known that with an increasing degree of unsaturation the peroxidizability of fatty acids increases. This may, to some extent, also be valid for in vivo systems such as cell membranes and in particular cytoplasmic fat, and could be responsible for an increased systemic vitamin $E$ requirement of animals given PUFA typical of fish oils.

The supplementation plan of $\mathrm{DL}-\alpha$-tocopheryl acetate in our experiment was calculated as follows: the vitamin E requirement for different PUFA is equal to the number of double bonds multiplied by a factor $\mathbf{0 \cdot 3}$, taking as a basis an absolute vitamin $\mathrm{E}$ requirement of $0.6 \mathrm{mg} / \mathrm{g}$ linoleic acid. For future experiments on the vitamin E-PUFA relationship it is important to be able to predict the vitamin E requirement on different high-PUFA diets to obtain a certain liver tocopherol status of rats. Under our experimental conditions the results of this study can be used to set up experiments where a constant vitamin $E$ status in combination with different dietary (and tissue) PUFA will be investigated. An example of this approach is given in Fig. 3, where the liver status of the CO 1 group (31 $\mu \mathrm{g} / \mathrm{g}$ with an intake of $2.3 \mathrm{mg} \mathrm{TE} / \mathrm{MJ}$ ) is taken as a reference value. In order to reach this liver $\alpha$-tocopherol concentration the high-PUFA diets should receive the following amounts of vitamin E: SF $3.1 \mathrm{mg}$, LN $3.4 \mathrm{mg}$ and FO $5.6 \mathrm{mg}$ TE/MJ. However, it is not known whether this tocopherol level gives adequate antioxidant protection for both the control groups and all high-PUFA groups. In order to get an idea about the adequacy of the 
vitamin $E$ intake in the high-PUFA groups we performed histopathological examination of adipose tissue. Steatitis was found in the non-supplemented as well as in the highest supplemented FO groups. The occurrence of steatitis in the adipose tissue of the FO groups clearly shows that the liver status of the FO group with the highest level of supplementation, which was higher than that of the control levels, does not mean that there is a sufficient vitamin $E$ supply in the adipose tissue of these animals. This indicates that a certain vitamin $E$ status may be adequate for some of the dietary fats but not for others (more unsaturated ones) and that the type of dietary fat may have an independent effect, possibly via the lipoprotein metabolism, on the tocopherol concentrations in the various tissues.

Feeding trials with animal models are relatively easy because the vitamin E and PUFA intakes can easily be manipulated and kept constant over a long period. Furthermore, various physiological and/or functional variables can be studied in the different tissues.

The present study shows how different dietary PUFA influence the vitamin E status of rats and how vitamin $E$ supplementation can have an impact on the vitamin $E$ status. Further work needs to be done to find measures that can be used to determine the optimal vitamin E status for any dietary PUFA (including linoleic acid).

The authors would like to thank J. M. Lansbergen, H. C. Moret and J. N. J. J. Mathot (analysis), A. J. van de Kooij and A. J. M. Keurntjes (histopathology) and F. H. Wijnen (animal care) for their excellent technical assistance.

\section{REFERENCES}

Bieri, J. G. \& Evarts, R. P. (1973). Tocopherols and fatty acids in American diets. Journal of the American Dietetic Association 62, 147-151.

Bjorneboe, A., Bjorneboe, G.-E. A. \& Drevon, A. (1990). Absorption, transport and distribution of vitamin E. Journal of Nutrition 120, 233-242.

Danse, L. H. J. C. (1989). Steatitis, subcutaneous and generalized, rat. In Integument and Mammary Glands, pp. 146-152 [T. C. Jones, U. Mohr and R. D. Hunt, editors]. Berlin: Springer-Verlag.

de Leenheer, A. P., de Bevere, V. O., Cruyl, A. A. \& Claeys, A. E. (1979). Simultaneous determination of retinol and $\alpha$-tocopherol in human serum by high-performance liquid chromatography. Journal of Chromatography $162,408-413$.

Department of Health (1991). Dietary Reference Values for Food, Energy and Nutrients for the United Kingdom. Report of the Panel on Dietary Reference Values of the Committee on Medical Aspects of Food Policy. Report on Health and Social Subjects 41. London: H.M. Stationery Office.

Deutsche Gesellschaft für Ernährung (1986). Empfehlungen für die Nährstoffzufuhr (Recommendations for Nutrient Intake), 4th edition. Frankfurt/Main: Umschau Verlag.

Farrell, P. M. (1988). Vitamin E. In Modern Nutrition in Health and Disease, pp. $340-354$ [M. A. Shills and V. R. Young, editors]. Philadelphia: Lea \& Febiger.

Food and Nutrition Board (1968). Recommended Dietary Allowances 7 th ed. Washington DC: National Academy of Sciences, National Research Council.

Food and Nutrition Board (1974). Recommended Dietary Allowances 8th ed. Washington DC: National Academy of Sciences, National Research Council.

Food and Nutrition Board (1989). Recommended Dietary Allowances 10th ed. Washington DC: National Academy of Sciences, National Research Council.

Green, J. \& Bunyan, J. (1969). Vitamin E and the biological antioxidant theory. Nutrition Abstracts and Reviews $39,321$.

Groot, P. H. E., de Boer, B. C. J., Haddeman, E., Houtsmuller, U. M. T. \& Hüllsman, W. C. (1988). Effect of dietary fat on the metabolism of triacylglycerol rich plasma proteins in the postprandial phase in meal fed rats. Journal of Lipid Research 29, 541-551.

Hamilton, J. G. \& Comai, K. (1988). Separation of neutral lipids, free fatty acid and phospholipid classes by normal phase HPLC. Lipids 23, 1150-1153.

Handelman, G. L., Machlin, L. J., Fitch, K., Weiter, J. J. \& Dratz, E. A. (1985). Oral $\alpha$-tocopherol supplements decrease plasma $\gamma$-tocopherol levels in humans. Journal of Nutrition 115, 807-813.

Harris, P. L. (1949). Practical nutritional aspects of vitamin E, introductory remarks. Annals New York Academy of Sciences 52, 240-242.

Harris, P. L. \& Embree, N. D. (1963). Quantitative consideration of the effect of polyunsaturated fatty acid content of the diet upon the requirements for vitamin E. American Journal of Clinical Nutrition 13, 385-392. 
Hirahara, F. \& Kimura, S. (1987). Effects of different dietary oil levels and vitamin E/PUFA ratio on tocopherol contents and lipid peroxidative values in serum and tissue of rats. In Clinical and Nutritional Aspects of Vitamin E, pp. 305-308 [O. Hayaishi and M. Mino, editors]. Amsterdam: Elsevier Science Publishers B.V.

Holman, R. T. (1954). Autoxidation of fats and related substances. In Progress in the Chemistry of Fats and Other Lipids, vol. 2, pp. 15-98 [R. T. Holman, W. O., Lundberg and T. Malkin, editors]. New York: Academic Press Inc.

Horwitt, M. K. (1960). Vitamin E and lipid metabolism in men. American Journal of Clinical Nutrition 8,451-461.

Jager, F. C. (1975). Linoleic acid intake and vitamin requirement. In The Role of Fats in Human Nutrition, pp. 381-432 [A. J. Vergroessen, editor]. London: Academic Press Inc.

Kinsella, J. A. (1988). Food lipids and fatty acids: importance in food quality, nutrition, and health. Food Technology, October 1988, 124-145.

Meydani, M., Cohn, J. S., Macauley, J. B., McNamara, J. R., Blumberg, J. B. \& Schaefer, E. J. (1989). Postprandial changes in the plasma concentration of $\alpha$ - and $\gamma$-tocopherol in human subjects fed a fat-rich meal supplemented with fat-soluble vitamins. Journal of Nutrition 119, 1252-1258.

Mouri, K., Ikesu, H., Ekasa, T. \& Igarashi, O. (1984). The influence of marine oil intake upon levels of lipids, $\alpha-$ tocopherol and lipid peroxidation in serum and liver of rats. Journal of Nutritional Science and Vitaminology 30, 307-318

Traber, M. G. \& Kayden, H. J. (1989). Preferential incorporation of $\alpha$-tocopherol vs $\gamma$-tocopherol in human lipoproteins. American Journal of Clinical Nutrition 49, 517-526.

Witting, L. A. \& Horwitt, M. K. (1964). Effect of degree of fatty acid unsaturation in tocopherol deficiencyinduced creatinuria. Journal of Nutrition 82, 19-33.

Witting, L. A. \& Lee, L. (1975). Dietary levels of vitamin E and polyunsaturated fatty acids and plasma vitamin E. American Journal of Clinical Nutrition 28, 571-576. 